University of Pennsylvania Carey Law School

Penn Law: Legal Scholarship Repository

Faculty Scholarship at Penn Law

1988

\title{
The Law and Economics of Collective Bargaining: An Introduction and Application to the Problems of Subcontracting, Partial Closure, and Relocation
}

\author{
Michael L. Wachter \\ University of Pennsylvania Carey Law School
}

George M. Cohen

University of Virginia - Main Campus

Follow this and additional works at: https://scholarship.law.upenn.edu/faculty_scholarship

Part of the Collective Bargaining Commons, Labor and Employment Law Commons, Labor Economics Commons, Law and Economics Commons, and the Political Economy Commons

\section{Repository Citation}

Wachter, Michael L. and Cohen, George M., "The Law and Economics of Collective Bargaining: An Introduction and Application to the Problems of Subcontracting, Partial Closure, and Relocation" (1988). Faculty Scholarship at Penn Law. 1510.

https://scholarship.law.upenn.edu/faculty_scholarship/1510

This Article is brought to you for free and open access by Penn Law: Legal Scholarship Repository. It has been accepted for inclusion in Faculty Scholarship at Penn Law by an authorized administrator of Penn Law: Legal Scholarship Repository. For more information, please contact PennlawIR@law.upenn.edu. 


\title{
University of Pennsylvania Law Review
}

FOUNDED 1852

\author{
Formerly \\ American Law Register
}

THE LAW AND ECONOMICS OF COLLECTIVE BARGAINING: AN INTRODUGTION AND APPLICATION TO THE PROBLEMS OF SUBCONTRACTING, PARTIAL CLOSURE, AND RELOGATION

\author{
Michael L. Wachter $\dagger$ and George M. Cohent†
}

Table of Contents

INTRODUCTION ..................... 1351

I. The Internal Labor Market Model ....... 1355

† Professor of Economics, Law, and Management; Director, Institute for Law and Economics, University of Pennsylvania.

H Law Clerk to the Honorable Walter K. Stapleton, United States Court of Appeals for the Third Circuit; Doctoral Candidate in Economics, University of Pennsylvania.

The authors would like to thank David L. Hall for his valuable contributions to an earlier draft of this Article, and Charles $T$. Joyce for his able research assistance. In addition, the authors would like to thank Peter Cappelli, Frank H. Easterbrook, Gerald R. Faulhaber, Robert A. Gorman, Douglas L. Leslie, Gerald L. Neuman, Clyde W. Summers and Randall D. Wright for their helpful suggestions. The authors also benefited from the stimulating insights provided by the participants at the University of Pennsylvania Law and Economics Seminar. Valuable research support was provided by the Institute for Law and Economics at the University of Pennsylvania. 
A. The Need for an Internal Labor Market: Job-Specific Training, Monitoring Costs, and Strategic Behavior

1. Transaction Costs in the Internal Labor Market

2. Graphical Analysis of the Internal Labor Market

B. Default Entitlement Settings in the Internal Labor Market .

1. Property Rules, Liability Rules, and Inalienable Entitlements in Labor Law ... . . . . . . 1367

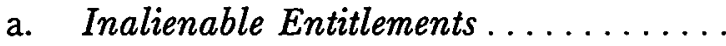
b. Liability Rules.
c. Property Rules

2. Bargaining Rules in Labor Law ......... 1371

a. Description of Bargaining Rules ..... 1372

b. Evaluation of Bargaining Rules ..... 1372

3. The Timing of Entitlement Settings ...... 1374
a. Event 1: The Signing of the Collective Bargaining Agreement
b. Event 2: Material Change in Economic Conditions

II. The Firm's Adaptation to a Decline in Product MARKeT CONDITIONS: AN INTERNAL LABOR MARKET APPROACH . . . . . . . . . . . . . . . . 1377

A. The Sunk-Cost-Loss Rule . .............. 1378

B. The Sunk-Cost-Loss Rule and the Protection of Default Entitlements.

C. Objections to the Sunk-Cost-Loss Rule ........

III. An Application of the Sunk-Cost-Loss Rule to Leading Labor Law CaSes ............... 1386

A. The Supreme Court Framework .......... 1386

1. Fibreboard ................. 1387

2. First National Maintenance............ 1390

3. Summary of Supreme Court Framework ... 1394

B. Subcontracting and Partial Closure Under the Supreme Court Framework ............... 1395

C. Work Relocation Under the Supreme Court Framework

1. The Economics of Relocation ... . . . . . . 1399

2. Otis Elevator II . . . . . . . . . . . . . . . 1402

3. Milwaukee Spring II .............. 1405 
a. Board Majority .............. 1407

b. Court of Appeals............... 1408

(i) Midterm Entitlement Protection... 1408

(ii) Default Entitlement Setting ...... 1409

(iii) Unresolved Midterm Relocation Issues................. 1411

c. Board Dissent .............. 1414

Conclusion ....................... 1415

\section{INTRODUCTION}

In many areas of the law, scholars have applied the methods and insights of economic analysis to evaluate the rationales for and the effects of legal rules. ${ }^{1}$ The theme running throughout the law and economics approach is that the law does not so much repeal market forces as restrict the channels through which those forces work. In common law areas such as contracts and torts, and in public law areas such as antitrust and securities regulation, law and economics scholars have shown that many legal rules, whether through explicit intent or not, have a tendency to foster efficient markets. ${ }^{2}$ In areas of statutory law, however, many of these scholars have argued that legal rules often do not promote efficiency, but that economic analysis is nevertheless useful to analyze the manner in which profit-maximizing parties respond to the incentives created by the rules. ${ }^{3}$

To date, few scholars have argued that American labor law is in any way attentive to or consistent with the goal of efficiency. ${ }^{4}$ In fact,

1 See, e.g., A. Polinsky, An Introduction to Law and Economics (1983); R. Posner, EConomic ANalysis of Law (3d ed. 1986). The current law and economics tradition dates back to Coase, The Problem of Social Cost, 3 J.L. \& Econ. 1 (1960).

${ }^{2}$ See generally R. POSNER, supra note 1, at 20-23 (distinguishing between positive economic analysis, "which explains legal rules and outcomes as they are rather than changing them to make them better," and normative analysis, the purpose of which is to "clarify value conflicts and to point the way toward reaching social ends by the most efficient path").

${ }^{3}$ See generally id. at 312 (arguing that statutory law is frequently a response to the demand for regulation by the parties who will benefit from it).

- A notable exception is Leslie, Labor Bargaining Units, 70 VA. L. Rev. 353 (1984). A number of other recent articles have used economic analysis to examine labor law. See Alchian, Decision Sharing and Expropriable Specific Quasi-Rents: A Theory of First National Maintenance Corporation v. NLRB, 1 SuP. CT. ECON. REv. 235 (1982); Campbell, Labor Law and Economics, 38 STAN. L. Rev. 991 (1986); Fischel, Labor Markets and Labor Law Compared with Capital Markets and Corporate Law, 51 U. CHI. L. Rev. 1061 (1984); Hall, Judicial Deference to Collectively Bargained Pension Agreements: The Implicit Economics of a Legal Standard, 4 HoFsTRA LAB. L.J. 111 (1986); Posner, Some Economics of Labor Law, 51 U. CHI. L. REv. 988 (1984); Schwab, Collective Bargaining and the Coase Theorem, 72 CoRnell L. Rev. 
recent works by law and economics scholars conclude that the primary purpose of labor law is to cartelize the labor market in order to enable workers to achieve higher wages than those that would be obtainable in an unregulated labor market. ${ }^{8}$ According to this view, labor law exemplifies the "capture theory" of regulation, which postulates that the government supplies regulation in response to the demands of interest groups seeking limits to competition and associated noncompetitive profits, wages, or returns to capital. ${ }^{6}$ Traditional labor law scholars share the view of these law and economics scholars that efficiency plays little part in labor law. ${ }^{7}$ But they treat economic analysis as essentially irrelevant, both to the labor market problem of unequal bargaining power that they envision and to the goals of industrial democracy and industrial peace that they espouse.

To the extent that these literatures contend or imply that efficiency is unimportant in interpreting labor law doctrine, this Article disagrees. $^{8}$ This Article argues that significant elements of labor law can

245 (1987); Note, An Economic Case for Mandatory Bargaining over Partial Termination and Plant Relocation Decisions, 95 YALE L.J. 949 (1986).

B See Campbell, supra note 4, at 1004-10; Posner, supra note 4. Judge Posner argues that

labor law is . . . founded on a policy that is the opposite of the policies of competition and economic efficiency that most economists support . . . . ... My basic thesis will be that American labor law is best understood as a device for facilitating, though not to the maximum possible extent, the cartelization of the labor supply by unions.

Id. at 990 . Posner does not attempt to rely on the explicit language of the labor statutes or the language of the cases to support the cartel theory. Although this Article does not object to the examination of implicit goals rather than explicit goals (the same technique is adopted below), it should be noted that the National Labor Relations Act ("NLRA") describes as one of its goals the "stabilization of competitive wage rates." NLRA $\S 1,29$ U.S.C. $\S 151$ (1982). This language suggests an appreciation of the goal of economic efficiency.

- See Peltzman, Toward a More General Theory of Regulation, 19 J.L. \& Econ. 211, 212 (1976); Posner, Theories of Economic Regulation, 5 BELL J. ECON. \& MGMT. ScI. 335, 341-43 (1974); Stigler, The Theory of Economic Regulation, 2 BELL J. Econ. \& Mgmr. ScI. 3, 3-4 (1971).

7 Most leading casebooks contain no discussion of the economic analysis of unions or of the labor market generally. See, e.g., A. Cox, D. Bok \& R. Gorman, Cases and Materials on Labor Law (9th ed. 1981); C. Summers, H. Wellington \& A. Hyde, Cases and Materials on Labor Law (2d ed. 1982). But see D. Leslie, Cases and Materials on Labor Law: Process and Policy 44-79 (2d ed. 1985).

${ }^{8}$ Certainly, one result of union behavior has been to raise wages above competitive levels. This point, which is central to the cartelization argument, see supra note 5 and accompanying text, is clearly supported by the empirical economic evidence. See Linneman \& Wachter, Rising Union Premiums and the Declining Boundaries Among Noncompeting Groups, 76 Am. Econ. Rev. Papers \& Proc. 103, 103 (1986). But see R. Freeman \& J. Medoff, What Do Unions Do? 162-81 (1984) (arguing that labor union premiums reflect productivity gains due to union presence). For a general critique of the effect of unions on relative wages, see B. Hirsch \& J. ADDISON, THE Economic Analysis of Unions: New Approaches and Evidence 116-54 (1986). 
be viewed as attempting to remedy market failures in internal labor markets.

One reason that labor law scholars have paid little attention to economic efficiency may be that they focus on the economic model of external labor markets. ${ }^{9}$ External labor markets-the markets for new employees-closely resemble the textbook economic model in which the supply of and demand for labor determine the wage. ${ }^{10}$ These markets approach allocative efficiency because of the mobility of workers and competition among firms for these workers. Under such circumstances, the law cannot enhance the efficiency of the economic result. Hence, if labor law is concerned with the external labor market, its focus must be on distributive or other noneconomic goals rather than allocative efficiency.

The internal labor market, on the other hand, is the market within a firm. ${ }^{11}$ In this market, workers seek career jobs, and the technology of firms makes it profitable for firms to supply such jobs. Because firms and workers invest in job-specific training ${ }^{12}$ and wage payment profiles conducive to low monitoring costs, both groups have a stake in main-

In addition, labor law rights, including the right to strike, in many respects involve political rather than economic issues. But these points should not obscure the argument that court interpretations of the NLRA are in many cases compatible with efficient contracting rules of labor economics.

- Posner and Campbell cite other reasons why economic analyses of labor law have not been undertaken. Posner argues that economists have avoided labor law because of its doctrinal complexity and that law and economics scholars are repelled by labor law's antiefficiency foundations. See Posner, supra note 4, at 989-90. This Article disagrees with the latter premise.

Campbell notes that some scholars object to analyzing labor like any other commodity, but responds that economics can be a useful guide to interpreting an unclear statute in a consistent way. In addition, Campbell states that some see economics as irrelevant to labor law because the NLRA's goals are largely redistributive rather than efficiency-related. To this objection, Campbell responds that even if redistributive goals are paramount, economics is useful for resolving ambiguous or unanticipated cases. See Campbell, supra note 4 , at 992-94.

10 Current views on the workings of the external labor market are explained in $R$. Ehrenberg \& R. SMith, Modern Labor Economics 167-392 (3d ed. 1988).

11 The treatment of the internal labor market in this Article follows that found in Williamson, Wachter \& Harris, Understanding the Employment Relation: The Analysis of Idiosyncratic Exchange, 6 BeLL J. Econ. \& MGMT. Scr. 250 (1975). For a general and institutional treatment of internal labor markets, see P. DOERINGER \& $M$. Piore, Internal Labor Markets and Manpower Analysis 13-63 (1971). Current work on internal labor markets builds upon such earlier research as that found in Dunlop, The Task of Contemporary Wage Theory, in NEW CONCEPTS IN WAGE DETERMination 117 (G. Taylor \& F. Pierson eds. 1957); Kerr, The Balkanization of Labor Markets, in LABOR MOBILITy AND ECONOMIC OPPORTUNITY 92 (E. Bakke ed. 1954); and Ross, Do We Have a New Industrial Feudalism?, 48 AM. Econ. Rev. 903 (1958).

12 The seminal work on specific training in internal labor markets is G. BECKER, Human Capital 26-37 (2d ed. 1975). 
taining a strong ongoing relationship. But because the resulting implicit, ${ }^{13}$ long-term contracting makes it costly for firms to replace workers and for workers to change jobs, a bilateral monopoly replaces the textbook model of competitive supply and demand. In this environment, asymmetric information and strategic behavior allow for inefficient outcomes. Section IA develops this internal labor market model in more detail.

In analyzing the internal labor market, this Article takes a Coasian perspective: ${ }^{14}$ the economic challenge for internal labor markets is to create "efficient labor contracts," which provide incentives for the parties to engage in joint profit maximization instead of acting strategically. Although the labor law literature and this Article focus on the statutes regulating unions and collective bargaining, ${ }^{16}$ the same Coasian analysis can be applied to nonunion internal labor markets as well. In this broader framework, collective bargaining and labor law rules represent one potential means of fostering efficient labor market contracting.

Section IB combines the internal labor market perspective with the Calabresi and Melamed framework, ${ }^{16}$ which views the law as assigning entitlements and protecting these entitlements with property, liability, and inalienability rules. In the context of labor law, another type of entitlement protection must be added. This rule is a "bargaining rule," or mandatory subject of bargaining, and is a basic method of protecting entitlements in labor law.

The Article then turns, in Part II, to the problem of how the labor law rules regulate a firm's adaptation to an unforeseen decline in its product market. The Article argues that the labor law rules applicable to subcontracting, partial closures, and relocation are consistent with efficient contracting in the internal labor market. ${ }^{17}$ This argument in-

13 Implicit contracting is discussed in R. EHRENBERG \& R. SMTTH, supra note 10 , at 406 , and described as "a set of shared, formal understandings about how firms and workers will respond to contingencies." Id.

14 See R. Posner, supra note 1, at 7, 19-20, 42-48; Coase, supra note 1, at 2-8. For a discussion of the Coase Theorem, see infra notes 24-26 and accompanying text.

${ }^{15}$ The main statutes are the National Labor Relations Act, Pub. L. No. 74-198, 49 Stat. 449 (1935) (codified as amended at 29 U.S.C. $\$ \S 151-169$ (1982)) and the Labor Management Relations Act, Pub. L. No. 80-101, 61 Stat. 136 (1947) (codified as amended at 29 U.S.C. $\$ \S 141-197$ (1982)).

${ }_{16}$ See Calabresi \& Melamed, Property Rules, Liability Rules and Inalienability: One View of the Cathedral, 85 HARv. L. Rev. 1089 (1972).

${ }^{17}$ There is an extensive economic literature on implicit labor market contracting. Recent surveys of that literature are in Parsons, The Employment Relationship: Job Attachment, Work Effort, and the Nature of Contracts, in 2 HANDBOOK OF LABOR EConomics 789 (O. Ashenfelter \& R. Layard eds. 1986); and Rosen, Implicit Contracts: A Survey, 23 J. ECON. LiTERATURE 1144 (1985). 
volves an efficient contracting rule, the "sunk-cost-loss rule," under which firms may act unilaterally in response to economic downturns as long as they incur a sunk cost loss. The most important component of the sunk-cost-loss rule is the $\mathrm{W}^{*} \mathrm{H}$ test, which allows a firm to cut its wage bill only by reducing hours of employment and not by reducing the wage rate. ${ }^{18}$

The Article in Part III then applies the sunk-cost-loss rule to the leading cases in the areas of subcontracting, partial closure, and work relocation. Part III begins with an economic rationale of the framework set forth by the Supreme Court in Fibreboard Paper Products Corp. $v$. $N L R B^{10}$ and First National Maintenance Corp. v. NLRB. ${ }^{20}$ A number of more recent National Labor Relations Board "NLRB" or "Board") cases dealing with subcontracting are then considered. Part III concludes by addressing the more complex problem of work relocation using two recent and influential NLRB cases, Milwaukee Spring $I I^{21}$ and Otis Elevator Co. $I I^{22}$ The sunk-cost-loss rule makes explicit the economic intuitions underlying these opinions and demonstrates a consistency across the cases that is not otherwise obvious.

\section{The Internal Labor Market Model}

Because the internal labor market model has not been analyzed using the law and economics methodology, the following discussion briefly reviews the essential tenets of this methodology before examining the specifics of the model. In this framework, economic analysis evaluates the efficiency of alternative labor law rules. ${ }^{23}$ In the internal labor market, efficient legal rules are those that jointly maximize the firm's profits and the workers' net compensation.

Economic analysis starts with a "polar case," that is, a hypothetical situation under which efficiency is achieved. The goal of the analy-

18 The theoretical framework of the $\mathrm{W} * \mathrm{H}$ test is discussed in Riordan \& Wachter, What Do Implicit Contracts Do?, 35 Indus. Rel. Res. A. Proc. 291, 294298 (1982); Grossman \& Hart, Implicit Contracts, Moral Hazard, and Unemployment, 71 AM. EcoN. REv. 301, 302, 306 (1981); Hall \& Lilien, Efficient Wage Bargains Under Uncertain Supply and Demand, 69 AM. EcoN. REV. 868, 870-75 (1979); and Holmstrom, Equilibrium Long-Term Labor Contracts, 98 Q.J. EcoN. 23, 23-26 (1983).

18379 U.S. 203 (1964).

20452 U.S. 666 (1981).

${ }_{21}$ Milwaukee Spring Div. of Ill. Coil Spring Co., 268 N.L.R.B. 601 (1984), affd sub nom. UAW v. NLRB, 765 F.2d 175 (D.C. Gir. 1985).

22 Otis Elevator Co., 269 N.L.R.B. 891 (1984).

${ }^{23}$ Although there are other values that the law explicitly pursues, these values are often consistent with efficiency. Even when they are not, efficiency may offer meaningful guidance when other values provide little. 
sis is to determine how existing institutions deviate from the polar case and to explore how policy may correct these deviations from efficiency. The polar case most often used in law and economics scholarship is Coasian bargaining, or zero transaction costs. In this polar case, the Coase theorem holds that the legal default setting does not affect the allocative outcome between two parties. Instead, the parties continually maintain allocative efficiency by engaging in every possible mutually beneficial transaction. ${ }^{24}$

Deviations from this polar case result from transaction costs. ${ }^{25}$ If transaction costs exist, inefficient outcomes may result. The existence of transaction costs in the internal labor market, however, does not alone provide a justification for government intervention. This is because private parties themselves have incentives to correct identifiable market failure and minimize transaction costs. Depending on the information available to government regulators, a public policy response to market failure may be more or less efficient than the private market response. ${ }^{26}$

The internal labor market model identifies the high transaction costs present in much labor bargaining and explores the institutions created by private parties and the government to reduce these costs. The following subsections introduce the internal labor market model and apply it to collective bargaining under the labor laws. Subsection A develops the rationale for and the components of the internal labor market. Subsection B uses the economic approach to entitlement setting to explore collective bargaining within the internal labor market.

\section{A. The Need for an Internal Labor Market: Job-Specific Training, Monitoring Costs, and Strategic Behavior}

To understand labor market failure, one must differentiate between two distinct markets in which firms and workers bargain: external and internal labor markets. ${ }^{27}$ In the external labor market, workers seek new job opportunities across firms. ${ }^{28}$ Similarly, firms seek new

24 See Schwab, supra note 4, at 256-61. Schwab discusses extensively the implications of the Coase Theorem for collective bargaining. The extent to which entitlements are in fact traded in the collective bargaining context is discussed infra notes 59-61 and accompanying text.

${ }^{25}$ For example, transaction costs of bargaining include the costs of negotiating, drafting, and enforcing agreements.

${ }^{26}$ See Coase, supra note 1 , at 17-18.

27 See P. Doeringer \& M. Piore, supra note 11, at 2 ("The internal labor market, governed by administrative rules, is to be distinguished from the external labor market of conventional economic theory where pricing, allocating, and training decisions are controlled directly by economic variables.").

${ }^{28}$ See R. Ehrenberg \& R. SMITH, supra note 10, at 14-15. Ehrenberg and Smith do not specifically define the external labor market. The "external labor market" 
employees to expand production or replace lost workers. Most firms and workers, however, deal with each other in a labor market that exists within the firm, a market comprised of long-term career workers and the firm that hired them. This market is termed the "internal labor market."20

The external labor market, on which economics textbooks concentrate ${ }^{30}$ matches the supply of workers with general skills to the demand of firms in need of such skills. The external labor market is both diverse and geographically large, since any given set of high school graduates may become semiskilled workers in firms as different as American Home Products, Citicorp, General Electric, Hospital Corporation of America, Safeway, or USX. The overwhelming evidence suggests that external labor markets are competitive, even more competitive than product markets. ${ }^{31}$ Hence, the textbook model of labor supply and demand reasonably describes the external labor market.

Internal labor markets develop as workers and firms establish ongoing contractual relationships ${ }^{32}$ and look less to the external market to sell and buy labor services. Because internal labor markets have relatively few participants, and all of them have limited mobility, the bargaining process poses problems of market failure and high transaction costs. $^{33}$ The parties attempt to minimize these transaction costs by writing efficient contracts, while government decisionmakers address the

to which this Article refers is analogous to what they describe as a "national labor market" or "local labor market," depending on its scope. See id. at 14.

${ }^{28}$ See id. ("When a formal set of rules and procedures guides and constrains the employment relationship within a firm, an internal labor market is said to exist."); id. at 159-60 (discussing how hiring from within creates an internal labor market); see also P. Doeringer \& M. PIORE, supra note 11, at 13-90 (developing the theoretical concept of the internal labor market).

so See, e.g., R. Dornbusch \& S. Fischer, Macroeconomics 377 (3d ed. 1984) ("The relationship among wages, prices, and employment and between employment and output will now be studied in an idealized frictionless case."); S. MAISEL, MACROECONOMICs 413 (1982) ("These assumptions include a market [in which p]rices are determined by perfect competition among firms and workers . . . .").

31 For example, Ehrenberg and Smith discuss labor market monopsony on only seven pages of their text. See R. EHRENBERg \& R. SMITH, supra note 10, at 70-73, 84-86. Their discussion indicates that monopsonistic labor markets are uncommon. See id. at 71-73; see also Fischel, supra note 4, at 1067 ("[A] substantial body of evidence suggests that labor markets are surprisingly competitive even in situations where intuition might suggest otherwise." (citing R. Higgs, CoMPETITION AND Coercion: BLACKS IN THE AMERICAN ECONOMY, 1865-1914 (1977); Roback, Southern Labor Law in the Jim Crow Era: Exploitative or Competitive?, 51 U. CHI. L. REv. 1161 (1984)).

${ }^{32}$ These contractual relationships can be either explicit, written contracts, or implicit, unwritten agreements. See R. EHRENBERG \& R. SMITH, supra note 10, at 40608. Implicit contracts are based on the mutual expectations of employers and employees. See id. at 160, 406.

${ }^{33}$ See Williamson, Wachter \& Harris, supra note 11, at 254. 
problem by setting default entitlements and enforcing explicit and implicit contractual provisions.

Labor law can be viewed, in part, as an attempt to lower the high transaction costs of internal labor markets while capturing the efficiency gains that such markets promise. ${ }^{34}$ This theory does not imply that policymakers are consciously motivated by economic efficiency; rather, this theory looks to the effects of policies that attempt to balance the interests of parties involved in economic disputes. The effects of labor law are in many cases, but not always, compatible with efficiency.

\section{Transaction Costs in the Internal Labor Market}

Internal labor markets emerge as an institutional response to the interest of workers in career jobs and the technological and cost efficiencies of using such workers. Thus, internal labor markets reduce some of the costs associated with exclusive use of external labor markets. But internal labor markets also exhibit high transaction costs, associated with job-specific training and monitoring, that give rise to asymmetric information and strategic behavior.

Job-specific training refers to training that has value primarily in a particular firm and is not transferable to alternative firms. ${ }^{35}$ Jobspecific training prepares workers for the special requirements of a given job, but consequently limits their ability to change jobs at low cost. On the other hand, job-specific training gives incumbent workers a productivity advantage over new workers. This productivity gap between incumbent and new workers shrinks the labor supply pool, which in turn violates one of the necessary conditions for competitive markets.

Monitoring refers to the fact that work effort can vary over a large range and that it is costly for firms to control work effort. Because of monitoring costs, firms cannot quickly and easily distinguish workers who perform up to standard from workers who shirk on the job.

${ }^{34}$ Fischel has identified several broad categories of transaction costs that differentiate labor markets from capital markets. See Fischel, supra note 4, at 1065-68. According to Fischel, "[t]he three most important differences are that capital markets are closer to the ideal of perfect competition than labor markets; that possibilities of firmspecific investments exist in labor markets that do not exist in capital markets; and that participants in labor markets have less ability to diversify risk." Id. at 1065 . The difference between the view expressed in this Article and Fischel's is that this Article finds these distinctions to be decisive rationales for different legal treatment of labor markets, while Fischel is more skeptical that the distinctions mandate different treatment. See id. at $1065-68$.

${ }^{35}$ See Williamson, Wachter \& Harris, supra note 11, at 256-58, 260-61. 
Job-specific training and monitoring are associated with the more general problem of asymmetric information ${ }^{36}$ Asymmetric information describes the fact that workers and firms have comparative advantages in gathering different types of valuable information. Incumbent workers have a comparative advantage in knowing their performance level and their opportunity wage ("OW"). These informational advantages allow incumbents to increase a firm's costs of monitoring work effort.

The firm, on the other hand, has its own informational comparative advantages. The firm is better able to determine the workers' marginal product ("MP"): the value of the workers to the firm based on product market conditions, net of monitoring costs. ${ }^{37}$ The firm's managers acquire inside information regarding the demand for the firm's product and hence the firm's derived demand for labor. ${ }^{38}$ The firm also has informational advantages concerning its technological opportunities, such as its ability to substitute capital for labor. ${ }^{39}$ These informational advantages make it costly for workers to monitor the firm's claims concerning product market conditions.

One possible solution to the problems created by asymmetric information is to delegate information gathering and reporting tasks to the lower cost party ${ }^{40}$ Assigning this responsibility to the lower cost party, however, poses a dilemma. The party that collects the information can use it strategically. ${ }^{41}$ Strategic behavior is the use of private information to realize individual profits at the expense of jointly maximized profits. ${ }^{42}$

${ }^{36}$ Asymmetric information is a well-known cause of market failure in economics. See, e.g., Akerlof, The Market for "Lemons": Quality Uncertainty and the Market Mechanism, 84 Q.J. EcoN. 488, 490-92 (1970).

${ }^{37}$ More precisely, the marginal product of a factor of production such as labor is the addition to the firm's output resulting from the last added unit of the factor. The marginal value product is the marginal product multiplied by the unit price of the output. See R. HELFGotT, LABOR ECONOMICs 299 (2d ed. 1980).

${ }^{38}$ The term "derived demand" refers to a demand for a commodity, such as labor, that depends upon the demand for the goods and services the commodity helps produce. See id. at 275.

${ }^{39}$ More generally, the firm knows the marginal rates of substitution across all factors of production. The marginal rate of substitution of one factor of production for another is simply the ratio of the marginal products of the two factors. See E. MaNsFIELD, Microeconomics: TheORY AND APPlications 136 (1970).

${ }^{40}$ See generally G. Calabresi, The Costs of Accidents 135-73 (1970) (discussing an analogous scheme in which accident costs are allocated to the party that could avoid them more cheaply).

41 See Riordan \& Wachter, supra note 18, at 293.

42 The term "strategic behavior" is often used more broadly in economics to denote a bargaining strategy under which the bargainer withholds or misrepresents private information. See, e.g., A. PolinSKY, supra note 1, at 18; Schwab, supra note 4, at 268-72. Strategic behavior in this broad sense may or may not lead to inefficient bargaining outcomes. Strategic behavior as used in this Article, however, is a subset of all 
Strategic behavior is made possible by "sunk investments"43 made by workers and firms in the internal labor market. When the parties make sunk investments, they expect to earn a future return, or quasirent, ${ }^{44}$ on these investments. But whether one party to an internal labor market contract receives its full expected quasi-rents after making an investment may depend on the actions of the other party. Specifically, one party can opportunistically expropriate the other party's return on investments, in which case the investing party suffers a "sunk cost loss."45 This potential for expropriating the investing party's quasirents, thus imposing a sunk cost loss, represents the bargaining power of the other party.

For example, workers make sunk investments in their jobs by agreeing to long-term implicit contracts that provide for "deferred compensation," that is, below-market wages at early stages of employment and above-market wages at later stages. ${ }^{46}$ There are two explanations

strategic behavior and is perhaps best defined as the inefficient breach of an implicit contract. A term for this type of behavior is "opportunism." See, e.g., Alchian, supra note 4, at 238; Williamson, Wachter \& Harris, supra note 11, at 258-59. But see Goetz \& Scott, Principles of Relational Contracts, 67 VA. L. Rev. 1089, 1101 (1981) (using the terms "opportunistic" and "strategic" behavior interchangeably).

\&s Sunk investments are investments that have already occurred and cannot be recalled. Cf. J. Quirk, InTermediate MrCRoeconomics 172 (3d ed. 1987) (stating that sunk costs, "represent water over the dam," because "no decision now is going to alter the firm's obligation [based on a previous contract] to pay them.").

14 Quasi-rents are net returns over maintenance costs that accrue to sunk investments. Quasi-rents are distinguished from pure economic rents. While economic rents "refer to any earnings beyond what is required to bring forth the services of the factor of production," quasi-rents are "the short-run earnings of any reproducible factor of production." Id. at 251. "More precisely, quasi-rent is any return to a resource above that necessary for its temporary existence." Alchian, supra note 4, at 238-39. Quasirents are described graphically in E. MANSFIELD, supra note 39, at 352-53.

t5 The term "sunk cost loss" has not been used before. It is more descriptive and less intimidating, however, than the more cumbersome term, "expropriated quasirents", and therefore it is used almost exclusively in this Article. The term "sunk cost loss" is not restricted to the loss of quasi-rents that have been expropriated by management or the union. It also encompasses the loss of any expected profit by any means, including product market adjustments, mismanagement, or any other decline in the firm's profitability.

48 In this discussion, the term "deferred compensation" does not refer only to pension plans, under which workers defer compensation until they retire. Rather, the term is used more broadly to encompass wages above opportunity wages in the latter part of an employee's worklife. Deferred compensation in this form can represent either returns to an investment in specific training or repayment of a bond posted by workers early in their careers as a means of monitoring their work effort. These types of deferred compensation schemes are commonly referred to as "backloading" of wages. See R. EHRENBERG \& R. SMITH, supra note 10, at 421-26.

In addition, the presence of transaction costs associated with worker mobility across firms generates a wedge between workers' wages and their opportunity wages. This wedge is also "deferred compensation," since we use this term to refer to any difference between wages and opportunity wages. 
for these sunk investments. First, workers invest in job-specific training, and deferred compensation represents the quasi-rents earned on this training. Second, workers invest in monitoring in the form of deferred compensation. In this case, the deferred compensation acts as a bond, and represents the potential penalty for shirking on the job. ${ }^{47}$ Once workers make a sunk investment in monitoring or job-specific training, the firm acquires bargaining power over them because it can strategically force the workers to suffer a sunk cost loss by misrepresenting product market conditions, thereby expropriating the workers' expected return.

Similarly, firms make sunk investments in workers by paying wages above marginal product at the beginning and end of a worker's career. The firm expects to earn a return on this investment during the middle years of the worker's career. Workers can deprive the firm of its expected return by misrepresenting their work effort. Reduced work effort forces the firm to increase its monitoring of workers, which lowers the workers' marginal products and with them the firm's profits.

The solution to the inherent dilemma posed by asymmetric information and strategic behavior is an efficient internal labor market contract. An efficient contract minimizes transaction costs by providing incentives for both parties to reveal their private information through their actions rather than to strategically misrepresent or conceal it. Since information disclosure is itself costly and can be used strategically by the other party, efficient contracts will not usually require actual disclosure. Rather, they create incentives under which the lower cost party automatically loses profits whenever it acts strategically, ${ }^{48}$ so that the contract is at least partially "self-enforcing."49

47 The monitoring argument was developed first by Lazear, Agency, Earnings Profiles, Productivity, and Hours Restrictions, 71 AM. ECON. REv. 606 (1981), and Medoff \& Abraham, Are Those Paid More Really More Productive?: The Case of Experience, $26 \mathrm{~J}$. Hum. Resources 186 (1981). Differentiation between the specific training and monitoring explanations of deferred compensation is discussed by Hutchens, $A$ Test of Lazear's Theory of Delayed Payment Contracts, 4 J. LAB. ECoN. S153 (1987).

The monitoring argument also arises in the law and economics literature on law enforcement. See, e.g., A. PolinSKy, supra note 1, at 73-84 (arguing that deterrence can often be maintained for risk-neutral people by increasing penalties while decreasing monitoring costs).

48 Another example of a self-enforcing legal rule is the rule of expectation damages for breach of contract. Expectation damages force the breaching party to compensate for the entire loss caused to the other party. Thus, if the breaching party still finds it profitable to breach the agreement, breach will be the efficient, profit-maximizing result. See A. Polinsky, supra note 1, at 27-28.

49 For a recent economic discussion of self-enforcing contracts, see Azariadis, Human Capital and Self-Enforcing Contracts, 90 SCandinavian J. Econ. (1988) (forthcoming). 


\section{Graphical Analysis of the Internal Labor Market}

The problem posed by strategic behavior can be demonstrated by a graphical analysis. Figure 1 plots three different relationships between representative workers' ages and the compensation they receive in the internal labor market. The workers enter the internal labor market at age $a$ and retire at age $f$.

\section{Figure 1}

Market Wages, Marginal Productivity, and Opportunity Wages over the Life Cycle

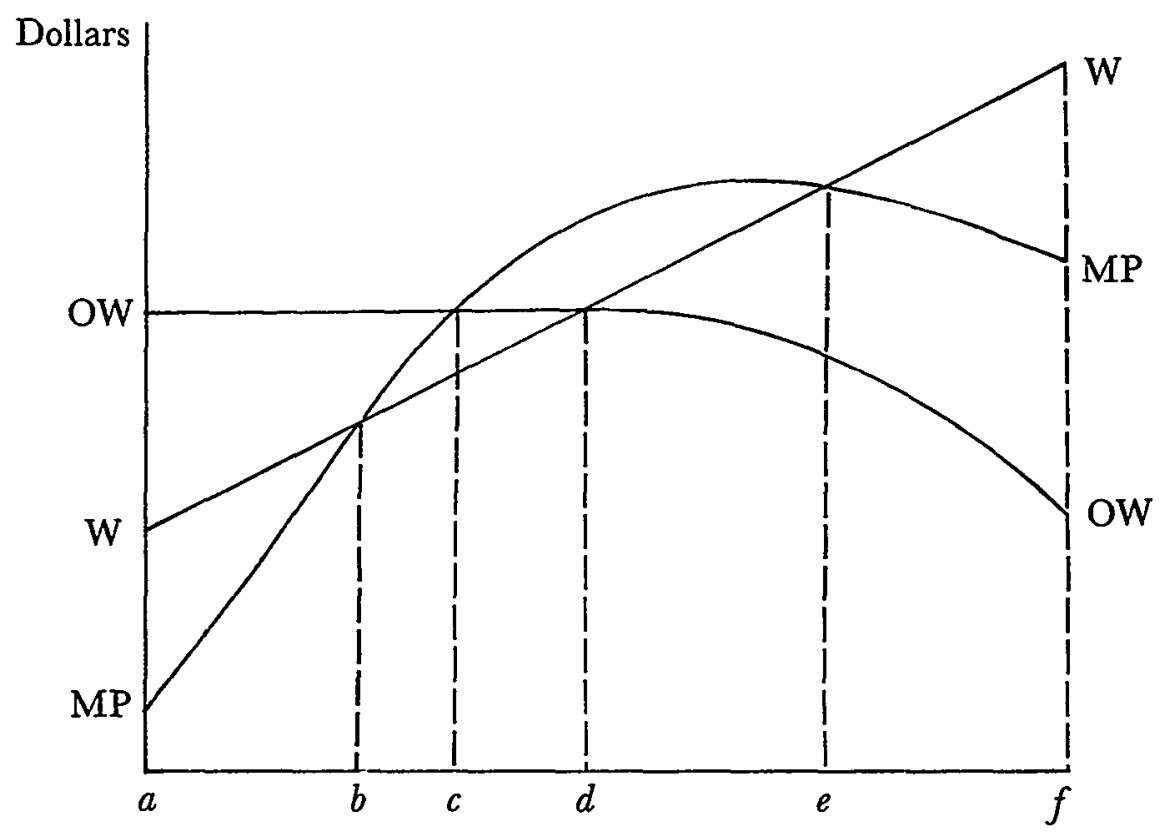

Key:

Age

W - wage paid by the firm to its workers

MP - productivity of the workers in their current jobs

OW - wage and productivity of the workers in the external labor market

The OW curve represents the workers' opportunity wage, which is the best alternative wage the workers could earn in the external labor market. Because the external labor market is competitive, ${ }^{50}$ workers remaining in that market throughout their worklife will always be paid 
their marginal product; thus, the OW curve represents workers' lifetime marginal productivity in the external market as well as their lifetime opportunity wage. For the sake of simplicity, it is assumed that $\mathrm{OW}$ is constant over much of the worklife, ${ }^{\mathbf{5 1}}$ and that it declines near the end of the worklife due to poor health and skill obsolescence.

The MP curve shows the workers' marginal productivity in their career jobs. ${ }^{62}$ Early in their careers, the untrained workers' MP is lower than their OW. This low productivity results from time spent in training activities and the relatively high cost of monitoring new workers. ${ }^{53} \mathrm{MP}$ then increases due to the effects of job-specific training and reduced monitoring costs, and beyond age $c,{ }^{, 4} \mathrm{MP}$ surpasses OW. ${ }^{55}$ As the workers get older, MP and OW decline for the same reasons: aging and obsolescence.

The $\mathrm{W}$ curve represents the career wage profile paid by the firm to its workers. Both the firm and the workers know the location of $W$. In an internal labor market job, workers' wages increase throughout their working careers. This age earnings profile reflecting deferred compensation is a key feature of an efficient labor market contract. ${ }^{56}$

The workers' investment pattern is shown by comparing $W$ with OW. When $\mathrm{W}$ is below OW, that is until age $d$, workers invest in monitoring and job-specific training by taking a lower wage than they can get elsewhere. They are willing to make this investment because after age $d, \mathrm{~W}$ exceeds OW. This return to the workers' own investment becomes their quasi-rent after they reach age $d$. The net return to the workers, discounted to present value, must be sufficient to encourage them to take a job that requires monitoring and job-specific training. Thus, it must at least equal the present value of lifetime OW.

The firm's investment pattern can be seen by comparing $W$ and MP. When W exceeds MP, the firm is investing, and when MP exceeds $W$, the firm is recouping. In Figure 1, the firm makes net investments until age $b$ and again after age $e$; between these two points, the

${ }^{\text {s1 }}$ That is, it is assumed that workers gain specific skills helpful to their career job, but not general skills that would raise their marginal productivity in any job and thereby raise their opportunity wage. But see G. BECKER, supra note 12 , at 26 (noting that much job training is partially specific and partially general).

${ }^{62}$ Their marginal productivity in other jobs, which are in the external labor market, is represented by OW. See supra text accompanying note 50.

${ }^{63}$ Time spent by a supervisor or other employee on training a new hire is also a cost imposed on the new hire's MP. '

34 The precise ordering of points $b, c, d$, and $e$ is not determined by the theory.

ss In the internal market, the sum of all MP points over the workers' lifetime equals the sum of all $O W$ points over their lifetime, discounted to present value, so that their averages are also equal. In the external market, where there is no long-term relationship between a firm and its workers, MP is equal to OW at all points.

${ }^{8 B}$ See supra notes $46-47$ and accompanying text. 
firm recoups its investment. The firm's net return, discounted to present value, must be sufficient to induce the firm to invest in monitoring and job-specific training.

The firm's primary mechanism for behaving strategically is to cut its wage rate (that is, to lower the $\mathrm{W}$ curve in Figure 1). The firm may be able to do this by convincing the workers that product market conditions have worsened (that the MP curve has shifted downward). The workers are vulnerable to false or exaggerated claims of product market decline because it is too costly for them to verify these claims or to take a different job. Workers are most vulnerable during the $e f$ stage. In that stage, workers are recouping their investments while the firm has already fully recouped its investment and is again a net investor. Moreover, at this stage, the difference between $W$ and OW is greatest. Thus, the workers in this stage of the worklife cycle have the most to lose from a strategic cut in W.

The workers' primary mechanism for behaving strategically is to impose monitoring costs on the firm by misrepresenting their performance level. Shirking lowers the MP curve and thereby imposes losses on the firm by reducing the amount it recoups on its investment. The firm is most vulnerable during its recoupment stage, $b e$. Workers can also behave strategically by threatening to quit. However, because workers do not fully recoup until the end of their careers, quitting is a less viable option than shirking.

Strategic behavior occurs not only as an initiative to capture the quasi-rents of the other party, but also as a reprisal. For example, if the workers believe that the firm is acting strategically, they can respond by imposing higher monitoring costs. The possibility of reprisals, which can lead to a cycle of strategic behavior, is important to the issue of efficient contract rules. An efficient contract rule that deters strategic behavior in the first instance also deters reprisals.

Figure 1's graphical analysis provides rough guidelines for measuring the potential profits from strategic behavior. For example, the steeper the age-earnings profile ("W" in Figure 1), the larger the employer's potential gains from strategic behavior, absent specific reasons to suppose that older workers are more efficient than younger workers. Conversely, the steeper the MP profile, the greater the workers' potential gains from strategic behavior.

\section{B. Default Entitlement Settings in the Internal Labor Market}

The preceding Section demonstrated that internal labor markets, which consist of ongoing contractual relationships between a firm and its workers, result from high transaction costs indigenous to labor rela- 
tions. Furthermore, efficiently operating internal labor markets minimize strategic behavior and thus foster and protect the specific training and monitoring of workers. This Section examines the role of labor law in creating and maintaining efficient internal labor markets.

According to the economic approach to contract law, legal rules are default settings: entitlements that apply in the absence of a contrary agreement, or in the presence of an ambiguous agreement, between contracting parties. Labor statutes and their interpretation by the Board and courts represent the default settings of traditional labor law. If these default settings are inefficient, and there are no transaction costs, including legal impediments, the entitlements will be traded between the parties to create an efficient entitlements setting. ${ }^{57}$

Even with positive transaction costs, the parties may be able to create efficient contracts on their own. For example, firms and workers may split both the cost of and return from such investments in specific training and monitoring. When both parties invest, they each have an incentive to avoid strategic behavior in order to protect their investments. ${ }^{58}$ In addition, general monitoring of management is often achieved through grievance procedures. Such procedures are cost-efficient means of reducing the potential for strategic behavior.

Private bargaining does not, however, successfully resolve all internal labor market problems. Not all transaction costs can be eliminated. Those that remain hamper the efficient trading of entitlements. ${ }^{59}$ For

57 See supra note 24 and accompanying text.

${ }^{58}$ See G. BECKER, supra note 12, at 26-37. Becker noted that the division of the burden "depend[s] on the relations between quit rates and wages, layoff rates and profits, and on other factors . . ., such as the cost of funds, attitudes toward risk, and desires for liquidity." $I d$. at 30 .

*9 In reaching this conclusion, the line of inquiry taken by Schwab, whose "thesis is that the Coase Theorem applies to a large and important class of labor law issues," Schwab, supra note 4, at 246, must be distinguished. Schwab does not go so far as to say that initial entitlements in labor law do not matter. See id. at 265 n.77 ("Indeed, the efficiency prediction of the Coase Theorem should . . . not be accepted as dogma, but rather as a hypothesis capable of empirical testing."). He is, however, optimistic that collective bargaining agreements are efficient. For example, Schwab argues that the "asymmetrical information problem can be overstated." Id. at 280 . In addition, he suggests that the "problem of strategic lying in labor negotiations" is mitigated in part by labor law's prohibition of such lying. Id. at 272 . To the contrary, this Article maintains that the problems of asymmetric information and strategic behavior are at the crux of understanding labor law rules.

Schwab does recognize that the internal labor market model may be a fruitful alternative to his approach, but he decides to limit his inquiry to the Coasian model:

Law and economics scholars may find it implausible to apply the Coase Theorem, with its assumption of zero transaction costs, to collective bargaining. An alternative model of relational contracts may ultimately prove equally useful in examining the effect of labor law on collective bargaining .... 
example, such trades may be the result of strategic exploitation of bargaining power possessed by one of the parties. In addition, as Professor Leslie has pointed out, ${ }^{60}$ many of the entitlements involved in labor law may not be traded once they are set because of large wealth effects and other problems. ${ }^{\text {B1 }}$ In the presence of transaction costs, the default settings established by legal rules have economic consequences. In setting default entitlements, therefore, the Board and courts often implicitly, if not explicitly, consider the economic consequences. ${ }^{62}$

There are two traditional criteria for setting entitlements: efficiency and equity. ${ }^{63}$ The efficiency criterion, which evaluates legal rules against a standard of joint profit maximization ${ }^{64}$ and reduced potential for strategic behavior, is the main focus of this Article. The equity criterion is concerned with the distribution of total profits. As Judge Posner suggests, one of the policies of the $\mathrm{NLRA}^{65}$ may be to redistribute income to unionized workers from other groups. ${ }^{66}$ Such redistribution may be difficult to achieve through entitlement-setting,

Rather than adopt the relational contract model, this Article applies the costless Coase Theorem to collective bargaining. It is important to see what insights basic Coasean analysis can shed on labor law, before investigating more complex models of collective bargaining.

Id. at 248-49 n.11.

For a discussion of the costs associated with internal markets, see supra notes 3549 and accompanying text.

${ }^{60}$ See D. LEsliE, supra note 7, at 369-73 (problems faced by labor negotiators include justifying to the union members the trading away of entitlements and the revelation of information on the union's true priorities that might be used strategically by management).

${ }_{61}$ Schwab and Leslie stake out the polar cases in the debate over the trading of entitlements. Schwab argues that transaction costs in labor negotiations are sufficiently low that inefficient entitlements will be traded frequently. See Schwab, supra note 4, at 267. Leslie, on the other hand, believes that transaction costs are sufficiently high that entitlements will rarely be traded, or "waived." See D. LESLIE, supra note 7, at 372.

This Article stakes out a middle ground by arguing that the transaction costs of strategic behavior and asymmetric information will sometimes prevent the efficient trading of entitlements, but that the parties are often able to overcome these transaction costs by writing efficient long-term contracts.

${ }^{62}$ See infra notes 138-262 and accompanying text.

${ }^{63}$ See Calabresi \& Melamed, supra note 16, at 1093-1105. Calabresi and Melamed categorize the criteria as "economic efficiency, distributional preferences, and other justice considerations." Id. at 1093. If equity is defined broadly to include all social preferences and merit considerations, then "distributional preferences" and "other justice considerations" become two types of equity criteria.

${ }_{\text {B4 }}$ Joint profit maximization does not factor in considerations of how the maximized profits are to be distributed; that question is one of equity, not efficiency.

${ }_{65} 29$ U.S.C. $\$ \S 151-169$ (1982).

6s See Posner, supra note 4, at 1001-04 (describing governmental support, through both the NLRA and enforcement decisions, of the "cartelization" of the labor market); cf. Fischel, supra note 4, at 1076-77 (criticizing the argument that unionization effects a favorable redistribution of wealth). 
however, because of the competitiveness of capital markets and external labor markets, which serve as substitutes for internal labor markets. When firms in capital markets and workers in external labor markets can bargain toward allocative efficiency, any redistribution resulting from inefficient entitlements in the union sector will be lost in the long run.

1. Property Rules, Liability Rules, and Inalienable Entitlements in Labor Law

To settle conflicts, an adjudicator.must make two determinations: which party to entitle and how to protect that entitlement. ${ }^{67}$ Entitlements can be absolute, which means that all or most uses of the resource are protected, or intermediate, which ultimately means that only some uses of the resource are protected. ${ }^{68}$ Intermediate entitlements are often more efficient than absolute entitlements. ${ }^{69}$

\section{a. Inalienable Entitlements}

Calabresi and Melamed, in their seminal article, ${ }^{\mathbf{7 0}}$ distinguish three means of protecting entitlements. First, an entitlement can be inalienable. ${ }^{71} \mathrm{~A}$ party assigned an inalienable entitlement may not trade it

67 See Calabresi \& Melamed, supra note 16, at 1090-93.

${ }^{68} \mathrm{Cf}$. W. Hirsch, LaW and ECONOMICS: AN INTROductory ANAlysis 18 (1979) (noting that an ownership right would allow the holder most uses, but not, for example, the right to limit the sale of property to a certain racial group, while a mere possessory interest may only allow for more limited uses); A. Polinsky, supra note 1, at 18 (discussing limits on property use, such as a resident's right to be free from factory pollution above a certain level, as intermediate entitlements).

69 The sunk-cost-loss rule, see infra notes 119-37 and accompanying text, is an example of an intermediate entitlement. It assigns the right to act to the firm, but restricts both the instances and the manner through which action can be taken. Likewise, the right to strike is an intermediate entitlement. Although employees striking over unfair labor practices are entitled on request to reinstatement and ouster of any replacement workers hired, employees striking over economic issues may not be able to regain their jobs from replacement workers. See R. Gorman, Basic TEXT ON LABOR Law: Unionization and Collective BaRgaining 341-43 (1976). The intermediate nature of the workers' right to strike is paralleled by the intermediate nature of an employer's ability to avoid strikes; even if the employer obtains a no-strike agreement from the union, the workers are free to strike over a serious unfair labor practice. See 2 The Developing Labor Law 1023-24 (C. Morris ed. 2d ed. 1983); The DevelopING LABOR LAW: Second Edition First Supplement 1982-84, at 259 (A. Harper, S. Logothetis \& H. Datz eds. 1985). Other limitations on workers' strikes also illustrate the intermediate nature of the entitlement. A union representing health-care workers, for example, must provide to the health-care employer a 10 -day notice of its intent to strike. See NLRA § 8(g), 29 U.S.C. § 158(g) (1982); 2 The Developing Labor LAW, supra, at 1005.

70 Calabresi \& Melamed, supra note 16.

${ }^{71}$ See id. at 1111-15; see also Rose-Ackerman, Inalienability and the Theory of 
away. Policymakers use inalienable entitlements when they determine that transaction costs are so high that efficient trades cannot be made. ${ }^{\mathbf{7 2}}$ In particular, if the potential for strategic behavior is great, it may be undesirable to allow the entitlement to be traded because of the danger that the trade represents strategic coercion ${ }^{73}$ or a sacrifice of long-term interests to achieve a short-term gain. ${ }^{74}$ Labor law makes relatively frequent use of inalienable entitlements because workers in internal labor markets are unusually susceptible to strategic behavior on the part of the firm. ${ }^{75}$ Examples of inalienable entitlements include the right of workers to unionize, ${ }^{76}$ the prohibition of company unions, ${ }^{77}$ and the rules governing union elections. ${ }^{78}$ Inalienable entitlements, however, are less difficult to determine and analyze than those that may be traded. Thus, this Article concentrates on alienable entitlements.

\section{b. Liability Rules}

The second way an entitlement can be protected is by a liability rule. Under a liability rule, a party may voluntarily trade the entitlement away, and another party may take the entitlement from the origi-

Property Rights, 85 Colum. L. Rev. 931, 931 (1985) ("Inalienability can be defined as any restriction on the transferability, ownership, or use of an entitlement.").

${ }_{72}$ See Calabresi \& Melamed, supra note 16, at 1112; Rose-Ackerman, supra note 71 , at $937-40$. Inalienability rules may also serve distributive goals, see Calabresi \& Melamed, supra note 16, at 1114-15; Rose-Ackerman, supra note 71 , at $940-41$, and paternalistic goals, see Calabresi \& Melamed, supra note 16, at 1113-14.

${ }^{73} \mathrm{Cf}$. Rose-Ackerman, supra note 71, at 940 (noting the prisoner's dilemma problem).

${ }^{74}$ See Calabresi \& Melamed, supra note 16, at 1113 (labeling this type of restriction "self paternalism").

${ }_{75}$ The ubiquity of inalienable entitlements in labor law contrasts with the paucity of such entitlements in corporate law, which governs financial markets. $C f$. Fischel, supra note 4, at 1062-68 (noting that corporate law operates from the assumption that firms have incentives to maximize investors' wealth, while labor law assumes that, absent regulation, firms will operate in a manner that oppresses labor).

${ }_{78}$ See NLRA $\& 7,29$ U.S.C. $\$ 157$ (1982). Although $\$ 7$ gives workers the "right to refrain from" joining a union, it does not allow workers to give up their right to join a union in return for, say, higher wages. $C f$. NLRA $\S 8(\mathrm{a})(3), 29$ U.S.C. $\S 158(a)(3)$ (1982) (making it an unfair labor practice for an employer to encourage or discourage union membership by using discriminatory terms of employment).

${ }_{77}$ See NLRA $\S 8(a)(2), 29$ U.S.C. § 158(a)(2) (1982) (making it an unfair labor practice for an employer to interfere with the formation of or to contribute financially to a labor organization).

${ }_{78}$ See NLRA $\S 9,29$ U.S.C. $\S 159$ (1982). For an analysis of inalienable rights in labor law, see generally Harper, Union Waiver of Employee Rights Under the NLRA: Part I, 4 INDUS. REL. L.J. 335 (1981) (attempting to formulate a principle limiting unions' ability to waive workers' rights); Harper, Union Waiver of Employee Rights Under the NLRA: Part II, A Fresh Approach to Board Deferral to Arbitration, 4 INDUS. REL. L.J. 680 (1981) (continuing analysis of union nonwaiver principles in the context of the effect of arbitration). 
nal entitlement holder, provided that the entitlement is paid for at a value assessed by a court or other adjudicatory body. ${ }^{79}$

In contract law, liability rule protection is typically used in breach of contract cases when the breach is efficient rather than strategic. ${ }^{80}$ In such cases, the breached-against party is protected by receiving the profits that would have been received had the contract been fulfilled. Such liability rule protection is efficient when the damages of the breached-against party are easy to measure. ${ }^{81}$

In internal labor markets, the potential for strategic breach is great. As a result, labor law makes relatively infrequent use of liability rules. For example, breaches of contract involving mandatory bargaining subjects are remedied by specific performance, sometimes supplemented with back pay, as determined by the Board, court, or arbitrator. ${ }^{82}$ Liability rule protection, however, typically holds when contract breach involves a nonmandatory subject of bargaining. ${ }^{83}$

In addition, the entitlements in internal labor markets are often idiosyncratic and hence have no readily available market substitutes against which they can be measured. ${ }^{84}$ As a consequence, the parties often do not rely on court-assessed damages ${ }^{85}$ and instead write contractual provisions that specify liquidated damages in the form of severance pay, pensions, early retirement, or other monetary compensation. ${ }^{\mathbf{8 6}}$ These liquidated damage clauses serve as a type of liability rule protection for laid off or discharged workers and typically are enforced by the Board and courts.

79 See Calabresi \& Melamed, supra note 16, at 1092.

so See R. Posner, supra note 1 , at 106.

81 See A. Polinsky, supra note 1, at 20-23.

82 Mandatory subjects of bargaining are discussed infra, notes 95-103 and accompanying text.

${ }^{83}$ If the parties reach an agreement on a nonmandatory subject, then the new entitlement is protected only by a liability rule. See Allied Chem. \& Alkali Workers of Am., Local Union No. 1 v. Pittsburgh Plate Glass Co., Chem. Div., 404 U.S. 157, 183-88 (1971).

84 See R. Ehrenberg \& R. Smith, supra note 10, at 159-60 (describing the difficulty of estimating costs and benefits within internal labor markets).

8s Conduct governed by the Act is not, however, immune from liability rules if damages can be easily computed by the adjudicating body. See, e.g., Virginia Elec. Power Co. v. NLRB, 319 U.S. 533, 540 (1943) (requiring employer to reimburse employees for union dues paid to an employer dominated labor organization); Truck Drivers, Local 705, 210 N.L.R.B. 210, 212 (1974) (requiring union, as a remedy for coercive practices, to reimburse employer for initiation fees and dues that employer paid on behalf of its employees); F.W. Woolworth Co., 90 N.L.R.B. 289, 291-94 (1950) (requiring back pay to be computed using a specific formula).

${ }^{86}$ See 2 Collective Bargaining Negot. \& Cont. (BNA) 48:1, 53:2 (1945). 


\section{c. Property Rules}

The third way way to protect an entitlement is by a property rule. Under a property rule, parties may voluntarily trade their entitlements, ${ }^{87}$ but entitlements may not otherwise be legally taken from them. ${ }^{88}$ Some examples of property rules in labor law include cease and desist orders, reinstatement orders, and findings of "no unfair labor practice" based on management prerogatives. Property rules are relatively efficient when lawmakers are fairly certain either which party values the entitlement more or which party is less likely to use the entitlement strategically. ${ }^{89}$ If the court or the Board uses property rules to resolve labor disputes, two polar options are available: to give the entitlement to act to the firm or give the entitlement to be free from the action to the workers. ${ }^{90}$

Assigning an entitlement to the firm and protecting it with a property rule essentially adds a legally implied "management rights clause" ally decide whether to take an action not explicitly addressed by the existing agreement. For example, in the absence of a specific prohibition in the labor contract, a court could assign to the firm the right to close a portion of its operations and to lay off union workers in response to changing market conditions. The workers would then attempt to bargain with the firm to preserve the status quo, possibly offering concessions in return for assurances that the firm would not take a particular action. However, if the firm's entitlement to take a particular action is protected by a property rule, it would be under no obligation either to bargain or to agree. ${ }^{\mathbf{9 2}}$

The opposite polar default setting, assigning the entitlement to the workers and protecting it with a property rule, would imply a complete rights."

87 A more traditional legal expression for the trading of entitlements is "waiver of

${ }^{88}$ See Calabresi \& Melamed, supra note 16, at 1092 (defining a property rule entitlement as something that may be taken only through purchase in a voluntary transaction).

${ }^{89}$ See A. Polinsky, supra note 1 , at 15-24 (examining the application of the Coase theorem to nuisance law); Calabresi \& Melamed, supra note 16, at 1106-10 \& n.37 (defining property and liability rules).

90 Of course, other options assigning intermediate entitlements are available, but the present discussion is limited to the options concerning absolute entitlements for simplicity.

91 A "management rights clause," also called "management prerogatives" or "management functions," is a contract clause that gives management the right to make unilateral decisions on issues that are normally subject to some degree of control by the union. See R. Gorman, supra note 69, at 505-06.

92 Labor law terms this situation "permissive bargaining." See id. at 523-25. 
"work preservation clause" into the labor contract. ${ }^{93}$ This rule would preserve the jobs and working conditions of employees according to the current practice under all circumstances. Unless the workers agreed to bargain with the firm and then further agreed to sacrifice jobs or wages in return for management concessions, the firm would be unable to take any action resulting in loss of jobs or a cut in wages that was not explicitly permitted by the contract. ${ }^{94}$

\section{Bargaining Rules in Labor Law}

The National Labor Relations Act, as interpreted by the Supreme Court, offers a fourth type of entitlement protection unique to collective bargaining in the unionized sector. The Board and the courts employ this kind of default setting by declaring an entitlement to be a "mandatory subject of bargaining." legal and the economic terminology, mandatory subjects of bargaining are referred to as "entitlements protected by bargaining rules." As discussed above, nonmandatory, or permissive, subjects are those entitlements protected by property rules. ${ }^{86}$ Accordingly, bargaining rules and property rules are mutually exclusive categories.

${ }^{93}$ In the nonunion sector, the default setting generally assigns the entitlement to make employment decisions to the employer and protects it with a property rule. There has been much discussion, however, regarding the possible erosion of this doctrine, known as employment at will. See, e.g., Blades, Employment at Will vs. Individual Freedom: On Limiting the Abusive Exercise of Employer Power, 67 Colum. L. Rev. 1404, 1404-05 (1967) (advocating limitations on employment at will doctrine because of potential employer abuses); Epstein, In Defense of the Contract at Will, 51 U. CHI. L. REv. 947, 952 (1984) (criticizing attacks on employment at will for ignoring nonlegal means of preserving long-term employment relationships and the greater imperfections of alternative rules); Linzer, The Decline of Assent: At-Will Employment as a Case Study of the Breakdown of Private Law Theory, 20 GA. L. REv. 323, 425 (1986) (advocating a return to common law creativity in reconciling employment at will and doctrines that weaken it); Summers, The Rights of Individual Workers: The Contract of Employment and the Rights of Individual Employees: Fair Representation and Employment at Will, 52 FORDHAM L. Rev. 1082, 1104-09 (1984) (advocating increased protection of individual contracts by protecting individuals against unjust dismissal and by limiting the common law employment at will doctrine). The change in the doctrine of at-will employment represents the limitations of and shifts in the legal default settings.

${ }_{\text {94 }}$ Property rule protection for workers may be appropriate if firms have made few sunk investments, and are therefore highly mobile, and workers have made great sunk investments, and are therefore highly immobile.

${ }^{85}$ The term "mandatory subject of bargaining" describes those subjects included in "wages, hours, and other terms and conditions of employment" over which NLRA $\S 8(d), 29$ U.S.C. $\S 158(d)$ (1982), requires bargaining. The Supreme Court adopted this terminology in NLRB v. Wooster Div. of Borg-Warner Corp., 356 U.S. 342, 34849 (1958). See also R. Gorman, supra note 69, at 498-509 (discussing the mandatory subjects of bargaining).

${ }^{88}$ Note, however, that if these entitlements are contained in an existing collective 


\section{a. Description of Bargaining Rules}

Under the bargaining rule, a party seeking either to assert a new entitlement or to change an existing entitlement concerning " "wages, hours, and other terms and conditions of employment" " commits an unfair labor practice by refusing to bargain in good faith to impasse when the other party desires to bargain. ${ }^{97}$ Thus, if a proposed term in a collective bargaining agreement involves an entitlement protected by a bargaining rule, the firm may not unilaterally implement the proposal without first bargaining to impasse. Moreover, each party is allowed to inflict certain costs (using "economic weapons") on the other party in support of its bargaining position. The union may strike, and the firm may lock out and replace the workers. ${ }^{98}$

Lastly, the parties themselves must resolve disputes over entitlements protected by a bargaining rule. The Board and the courts will not determine entitlements protected by a bargaining rule as they will other entitlements. ${ }^{98}$ Once the parties set the entitlement in their collective agreement, however, the Board and the courts will protect that entitlement, usually with a property rule. ${ }^{100}$

\section{b. Evaluation of Bargaining Rules}

Bargaining rules exist to restrict the parties' ability to act strategically. Because bargaining rules allow either side to impose costs on the other (through strikes and lockouts), both sides have an incentive not to behave strategically. This ability of either party to punish strategic behavior can result in a harmonious long-term contracting relationship.

agreement, they are protected by liability rules. See supra note 83 .

${ }_{97}$ See NLRB v. Katz, 369 U.S. 736, 742-43 (1962) (quoting NLRA § 8(d), 29 U.S.C. $\$ 158$ (d) 1982)); Borg-Warner Corp., 356 U.S. at 348-49 (same). By contrast, under property rule protection, the holder of the entitlement has no duty to entertain offers to sell the entitlement.

${ }_{98}$ See American Shipbuilding Co. v. NLRB, 380 U.S. 300, 318 (1965) (upholding employer's right to lock out the union after negotiations have reached impasse if the purpose of the lockout is to bring to bear economic pressure on the union); NLRB $v$ Mackay Radio \& Tel. Co., 304 U.S. 333, 344 (1938) (noting that a union may lawfully strike as a consequence of a current labor dispute).

${ }_{98}$ See H.K. Porter Co. v. NLRB, 397 U.S. 99, 108 (1970) ("[A]llowing the Board to compel agreement . . . would violate the fundamental premise on which the Act is based-private bargaining under governmental supervision of the procedure alone, without any official compulsion over the actual terms of the contract.")

100 See NLRA \& 8(d), 29 U.S.C. \& 158(d) (1982) ("The duties imposed upon employers, employees, and labor organizations . . . shall not be construed as requiring either party to discuss or agree to any modification of the terms and conditions contained in a contract for a fixed period ...."). 
Thus, bargaining rules are the keystone of the labor laws and are applied to a broad range of entitlements. ${ }^{101}$

On the other hand, bargaining rules are a very costly form of entitlement protection. In particular, the process of collective bargaining is costly. Drafting an acceptable collective bargaining agreement involves time, data collection, and legal expenses. More important, strikes and lockouts-the results of failed negotiations-may impose significant costs on both sides. In general, bargaining rules are rules governing process and thus cannot ensure an efficient outcome.

An interesting issue involving the cost of bargaining rule protection concerns the degree to which each side must provide information to the other during negotiations. ${ }^{102}$ Although full information sharing may seem attractive, such a rule would rarely be efficient. First, collecting and sharing the relevant information creates direct costs. Second, the distribution of product market information to the union increases the risk of a leak of confidential data that could threaten a firm's profit maximizing strategies. Third, and perhaps most important, once equipped with the other side's information, each party is in a better position to bargain strategically, since it will then be able to determine the size of the quasi-rents it can expropriate. ${ }^{103}$ Accordingly, the effi-

101 The Board and the courts have interpreted "wages, hours, and other terms and conditions of employment" broadly to include piecework and incentive pay plans, see Katz, 369 U.S. 736, the effects of plant closings, see Fibreboard Paper Prods. Corp. v. NLRB, 379 U.S. 203 (1964), group health insurance, see W.W. Cross \& Co. v. NLRB, 174 F.2d 875 (1st Cir. 1949); see also Allied Chem. Workers v. Pittsburgh Plate Glass Co., 404 U.S. 157, 159 (1971) (citing W.W. Cross with approval), store operating hours, see Local 189, Amalgamated Meat Cutters v. Jewel Tea Co., 381 U.S. 676 (1965), safety rules, see NLRB v. Gulf Power Co., 384 F.2d 822 (5th Cir. 1967), hiring practices, see Phelps Dodge Corp. v. NLRB, 313 U.S. 177 (1941); Houston Chapter, Associated Gen. Contractors of Am., Inc., 143 N.L.R.B. 409 (1963), enforced sub nom. NLRB v. Houston Chapter, Associated Gen. Contractors of Am., Inc., 349 F.2d 449 (5th Cir. 1965), cert. denied, 382 U.S. 1026 (1966), and dispute resolution provisions, see NLRB v. Boss Mfg. Co., 118 F.2d 187 (7th Cir. 1941). See generally R. GORMAN, supra note 69, at 496-509 (discussing mandatory subjects of bargaining).

${ }_{102}$ See NLRB v. Truitt Mfg. Co., 351 U.S. 149, 152-54 (1956) (holding that employer committed unfair labor practice by claiming during negotiations that it could not afford to pay higher wages, but refusing to produce information substantiating its claim); Detroit Newspapers Printing \& Graphic Communications Local 13, 233 N.L.R.B. 994, 995-96 (1977) (union has a similar duty to furnish information to employers). The types of information that employers must supply include, when relevant, documentation of an argument that market forces dictate a bargaining position, wage information, insurance plan cost information, job classifications and studies, and other information regarding terms and conditions of employment. Unions have been required to provide information regarding hiring hall and employment referral procedures, collective bargaining agreements with other employers, and information pertinent to pension and welfare plans. See 1 The Developing LABOR LAw, supra note 69, at 62129.

103 One commentator argues that the provision of information actually reduces costs, and suggests that the requirement of provision of information be extended: "AI- 
cient rule would not require full information disclosure but would instead seek to limit actual disclosure and replace it with self-enforcing contracts that disclose the relevant information indirectly.

\section{The Timing of Entitlement Settings}

Both bargaining rules and property rules are costly, ${ }^{104}$ but there are situations in which one rule is arguably more efficient than the other. ${ }^{105}$ Two events in particular form a dividing line between use of bargaining rules and use of property rules: the signing of the collective

though the bargaining requirement necessarily imposes some transaction costs on the parties by requiring good faith bargaining until impasse, . . . the good faith standard's requirement of information disclosure at the same time contains those transaction costs. Required information disclosure severely limits much opportunistic bargaining." Note, supra note 4, at 964 n.80. Even that student commentator, however, acknowledges that

opening up discussions before a proposed move may also reduce the productivity of the employer's workforce simply by providing the workers with notice of a possible plant closing. The most productive workers may take quick advantage of their marketability and leave before the closing would occur, and all workers, fearing imminent job loss, may devote more attention to their possible forthcoming job search than to their current jobs.

Id. at $958 \mathrm{n} .57$; see also id. at 960 ("The union could negotiate in an honest effort to reach a mutually acceptable agreement or it could negotiate in an effort to forestall the threatened shutdown or relocation while its members, unwilling to concede, begin their job search."(citation omitted)).

Yet the commentator concludes that the requirement that the union bargain in good faith, imposed by NLRA $\S 8($ b)(3), 29 U.S.C. $§ 158(\mathrm{~b})(3)$, "ensures the 'quality' of the union's intent to some extent and promotes mutually beneficial exchange." Id. at $964 \mathrm{n.79}$. There is no reason to believe, however, that a vague good faith requirement would control strategic behavior by the union any more than it would control such behavior by the firm. Rather, strategic behavior is more effectively controlled by contractual terms that force both parties to reveal their private information through their actions.

${ }_{104}$ Not all commentators agree that bargaining rules are costly and so must be restricted. See, e.g., Cox, The Duty to Bargain in Good Faith, 71 HaRv. L. Rev. 1401,1412 (1958) ("The cost [of bargaining] is so slight that the potential gains easily justify legal compulsion to engage in the discussion.").

${ }_{105}$ The Supreme Court has taken such an efficiency approach to mandatory subjects of bargaining. See First Nat'l Maintenance Corp. v. NLRB, 452 U.S. 666, 678-79 (1981). The Court stated:

The concept of mandatory bargaining is premised on the belief that collective discussions backed by the parties' economic weapons will result in decisions that are better for both management and labor and for society as a whole. . . . [I]n view of an employer's need for unencumbered decisionmaking, bargaining over management decisions that have a substantial impact on the continued availability of employment should be required only if the benefit, for labor management relations and the collective-bargaining process, outweighs the burden placed on the conduct of the business.

Id. (citation omitted). 
bargaining agreement and an unanticipated change in economic conditions.

\section{a. Event 1: The Signing of the Collective Bargaining Agreement}

During the contract formation process, bargaining rules predominate. The signing of the collective bargaining agreement then allocates entitlements previously protected by bargaining rules (the mandatory subjects) as well as those previously protected by property rules (the nonmandatory subjects). Once a collective agreement is signed, however, all mandatory subjects of bargaining on which the parties specifically reach agreement become protected by property rules. ${ }^{108}$ Thus, no party can unilaterally modify or force bargaining over a mandatory subject contained in the contract.

If, however, the collective agreement is silent regarding a mandatory subject, bargaining rule protection still theoretically applies. That is, "midterm bargaining," which occurs during the term of a collective agreement, does not differ in any legal way from "endterm bargaining," which occurs before the collective agreement is signed. The practical differences, however, are great. ${ }^{107}$

These differences arise because the parties themselves typically limit the application of bargaining rules midterm by writing property rule protections into the agreements. ${ }^{108}$ Most collective agreements contain no-strike clauses, which prohibit midterm strikes. ${ }^{109}$ Without the ability to strike, the protection accorded to workers by a bargaining rule is limited: a firm can satisfy its statutory obligations by bargaining to impasse and then acting unilaterally without fear of direct reprisal. ${ }^{110}$

A no-strike clause often accompanies an arbitration clause, which requires that any dispute about the meaning of the collective agreement be submitted to arbitration. ${ }^{111}$ The union's ability to arbitrate midterm substitutes to some degree for its foregone ability to strike midterm;

${ }^{108}$ See supra note 100 and accompanying text.

107 One practical difference is that endterm bargaining usually occurs in the conjectural stage. See infra notes 117-18 and accompanying text.

${ }^{108}$ See generally R. Gorman, supra note 69, at 604-06 (discussing the evolution of "mature bargaining," which is characterized by contractual provisions for peaceful dispute resolution).

${ }^{109}$ See 2 Collective Bargaining Negot. \& Cont. (BNA) 77:1 (1986).

110 See, e.g., Taft Broadcasting Co., 163 N.L.R.B. 475, 478 (1967) ("[A]fter bargaining to an impasse, that is, after good-faith negotiations have exhausted the prospects of concluding an agreement, an employer does not violate the Act by making unilateral changes that are reasonably within his pre-impasse proposals."), enforced sub nom. AFTRA v. NLRB, 395 F.2d 622, 629 (D.C. Cir. 1968).

111 See 2 Collective Bargaining Negot. \& Cont. (BNA) 51:1 (1986). 
thus, the Supreme Court has called the arbitration clause a "quid pro quo" for the no-strike clause. ${ }^{112}$ But the substitution is not perfect; the arbitrator cannot use bargaining rules and must rely instead only on property rules and liability rules. Thus, the use of arbitration further diminishes the practical role of mandatory midterm bargaining.

In addition to no-strike and arbitration clauses, the parties often include broad zipper clauses, which attempt to prohibit bargaining over any mandatory subject during the term of the collective agreement, whether or not the parties actually considered the subject at endterm. ${ }^{113}$ Most collective agreements also contain broad management rights clauses, which purport to give the firm wide discretion to act unilaterally in areas not covered explicitly by the agreement. ${ }^{114}$ Zipper clauses and management rights clauses represent further attempts by the parties to reduce the costs of mandatory bargaining by replacing bargaining rules with property rules during the term of the collective agreement.

The fact that parties so severely limit the force and application of bargaining rules midterm suggests that property rule protection is generally more efficient midterm. The parties recognize that due to the costs of bargaining rules, restricting their use to the discrete intervals when the contract is open for renegotiation will ordinarily lead to joint profits higher than when either side can force negotiations midterm. Courts may have recognized this fact also. For example, if courts and the Board read broadily the concept of an entitlement "contained in" the agreement (so that an entitlement can be found in a broadly worded or substantively related clause), then the use of midterm bargaining rules can be minimized. The District of Columbia Circuit has taken such an approach to midterm entitlements in its Milwaukee Spring $I I^{115}$ decision, discussed in the last Section of this Article. ${ }^{116}$

\section{b. Event 2: Material Change in Economic Conditions}

The second event that triggers a restriction of bargaining rules is a material change in economic conditions, such as a recession. Before the parties know that a change will occur, they are in the "conjectural" (1960).

112 See United Steelworkers of Am. v. American Mfg. Co., 363 U.S. 564, 567

113 See 2 Collective Bargaining Negot. \& Cont. (BNA) 36:421 (1987).

114 See 2 Collective Bargaining Negot. \& Cont. (BNA) 65:1 (1986).

11 UAW v. NLRB, 765 F.2d 175 (D.C. Cir. 1985) aff $g$ Milwaukee Spring Div. of Ill. Coil Spring Co., 268 N.L.R.B. 601 (1984).

${ }_{116}$ See infra notes 220-262 and accompanying text. 
stage in which they bargain about hypothetical occurrences. ${ }^{117}$ In the conjectural stage, mandatory bargaining is relatively efficient because it provides a low-cost means for the parties to decide how to allocate foreseeable risks between themselves. Workers could, for example, insure against future product market declines by offering concessions in return for a job preservation clause or severance pay provision in the contract. On the other hand, firms could provide for greater freedom to adjust input costs during economic downturns by bargaining for a clause allowing subcontracting or relocation of work. Since contracts embody the parties' willingness to make tradeoffs, private entitlements established by the parties in the conjectural stage pursuant to mandatory bargaining will be superior to public determination of entitlements by the Board or the courts.

In the "nonconjectural stage," on the other hand, an event has occurred that is not explicitly provided for in the contract. In this stage, the costs associated with mandatory bargaining become more burdensome. ${ }^{118}$ In the place of bargaining, therefore, the contract should be scrutinized to see how the parties implicitly allocated the losses in the event of such contingencies. For example, the presence of a layoff clause could be understood to mean that the firm is allowed to lay off workers in response to an economic downturn, as long as the firm follows the seniority schedule in making these layoffs.

In summary, bargaining rules are generally the efficient default settings at endterm and in conjectural cases. In contrast, property rules are efficient default settings at midterm and in the nonconjectural stage, so long as some provision is made to protect against strategic behavior. That provision, the sunk-cost-loss rule, is the subject of the next Part.

\section{The Firm's Adaptation to a Decline in Product Market Conditions: An Internal LABOR Market APPROACH}

This Part applies the internal labor market model to a problem

${ }^{117}$ See Otis Elevator Co., 269 N.L.R.B. 891, 899 n.16 (1984) (concurrence of Member Dennis) (distinguishing between situations in which the burdens imposed by the terms are merely speculative and those in which a party makes a "nonconjectural economically motivated decision" affecting the same subject matter). Economists would use the terms "ex ante" and "ex post" to describe the conjectural and nonconjectural stages.

118 The Supreme Court has recognized that "management may have great need for speed, flexibility, and secrecy in meeting business opportunities and exigencies. . . . The employer also may have no feasible alternative to the closing, and even good-faith bargaining over it may both be futile and cause the employer additional loss." First Nat'I Maintenance Corp. v. NLRB, 452 U.S. 666, 682-83 (1981) (footnote omitted). These problems all relate to the nonconjectural stage. 
that has become increasingly important in labor law: the need for a firm to respond to a decline in the product market through subcontracting, partial closure, or work relocation. In the internal labor market model, the firm's adaptation to changing market conditions raises the inherent dilemma of efficient labor contracting posed in Part I. The allocation of responsibilities that is most efficient is one that gives the firm the entitlement to decide on the scale and scope of operations in the depressed product market. That entitlement recognizes the firm's cost advantage in gathering and adjusting to new product market information. At the same time, the efficient entitlement must also restrict the firm's ability to act strategically.

The "sunk-cost-loss rule," defined and explained in this Part, accomplishes the above task. The economic literature on efficient labor market contracts suggests that the sunk-cost-loss rule is one of the efficient, implicit contractual terms found throughout internal labor markets in both union and nonunion sectors. ${ }^{119}$ The rule can be interpreted as one that the parties themselves would write in a low-transaction cost setting. The rule permits changes that are consistent with joint profit maximization, while preventing moves that are profitable to the firm only because of strategic gains at the expense of the workers.

This Article maintains that the labor law rules governing subcontracting, partial closure, and work relocation are compatible with the sunk-cost-loss rule. Although it has not been explicitly stated by either the Board or the courts, the rule explains the economic intuition underlying recent legal decisons. ${ }^{120}$ Because the economic rule indicates a common (if unrecognized) thread among recent major court and Board decisions, a fuller understanding of it can better focus the legal analysis of new cases.

\section{A. The Sunk-Cost-Loss Rule}

The sunk-cost-loss rule is a rule of thumb that assigns to firms the entitlement to respond to changes in product market conditions, while at the same time limiting the channels through which the firm can adjust to these changes. Under the sunk-cost-loss rule, the firm has broad power to determine the scale and scope of its operations. The entitle-

119 See supra note 18 and accompanying text.

120 The sunk-cost-loss rule is neither a statutory nor a common law legal requirement. It is an efficient standard that has developed in the internal labor market as a response to transaction costs inherent in the market. Thus, the term "rule" is used to identify those transactions to which rational parties would agree in a low-transactioncost setting. For a discussion of how the rule is combined with labor law default settings, see infra notes 128-29 and accompanying text. 
ment is intermediate, rather than absolute, because the firm must accept a sunk cost loss in the process of reducing its total labor costs, or wage bill. ${ }^{121}$

The sunk cost loss suffered by the firm is the loss of expected profits accruing to the firm's sunk investments in labor (through specific training and monitoring) and in physical capital. ${ }^{122}$ The sunk-cost-loss rule deters strategic behavior by both parties. The firm is less likely to act strategically, by expropriating the workers' deferred compensation, if in order to cut its wage bill the firm must simultaneously suffer lost expected profits. In addition, workers are less likely to retaliate strategically by increasing monitoring costs because the sunk cost loss incurred by the firm provides objective evidence to the workers that supports the firm's claim of a product market decline.

Ideally, workers would be able to verify a firm's sunk cost losses by observing the reduced profits and output associated with a decline in the firm's product market. But these changes may be difficult to measure directly. What can be verified are the sunk cost losses associated with investments in the firm's inputs, which, when combined with the firm's production technology, ${ }^{123}$ create the output. The two main categories of inputs are labor, or total hours $(\mathrm{H})$, and capital (K). Thus, proxy variables representing $\mathrm{H}$ and $\mathrm{K}$ enable workers and adjudicative bodies to test for lost profits without the need to examine the firm's balance sheet.

A major variant of the sunk-cost-loss rule is the $\mathrm{W} * \mathrm{H}$ test. The $\mathrm{W} * \mathrm{H}$ test requires the firm to reduce its wage bill $(\mathrm{W} * \mathrm{H})$ through a reduction in total hours $(H)$ rather than the wage rate $(W) \cdot{ }^{124}$ The firm can cut $\mathrm{W}$ without incurring a sunk cost loss; therefore, allowing the firm to make unilateral changes in $\mathrm{W}$ would not deter strategic behavior.

When a firm suffers a decline in the demand for its product, it must retrench by cutting either output or marginal costs, or some combination of the two. If marginal costs were reduced through a reduction

121 The wage bill is the product of the wage rate and the total hours worked at that rate summed over the various rates existing in the firm.

${ }^{122}$ Alternatively, a sunk cost loss is a loss of quasi-rents. See supra notes $43-45$ and accompanying text.

${ }^{123}$ In economics, the firm's technology is represented by the production function. The production function takes a form similar to $f(K, L)=Q$, in which $K$ and $L$ represent capital and labor respectively, $Q$ represents output, and $f$ represents the functional form that captures the technological relationship between the firm's inputs and outputs. See R. EHRENBerg \& R. SMITH, supra note 10, at 55-56.

$124 \mathrm{~W}$ is used herein to represent not only the literal wage rate, but also all other forms of compensation. See generally id. at 21-24 (discussing wages and other forms of compensation). 
in wage rates, profits and output could remain unchanged and the firm would incur no sunk cost loss. ${ }^{125}$ If the firm had the entitlement to cut wages, therefore, it would have an incentive to fabricate or overstate the decline in the demand for its product and could actually increase its profits. Thus, the firm could behave strategically by seizing the deferred compensation owed to its workers. Of course, the firm would not lower wages below the opportunity wage (OW), net of the costs of finding a new job, because the workers would then quit, but the firm would have an incentive to lower $W$ to just above $O W$.

If output were reduced, in contrast, then hours of work and profits would decrease from previous levels and the firm would incur a sunk cost loss. Since any overstatement of the degree of product market decline would cause the firm to reduce its output and profits below profitmaximizing levels, the firm is deterred from engaging in strategic overstatement of a decline in its product market. In this sense, the sunkcost-loss rule has important self-enforcing qualities.

But a further restriction is needed. As shown in Figure 1, the firm may employ experienced workers who are in the recoupment phase of their investment in training and monitoring: those in the $d f$ region. And the firm may also employ workers on whom the firm is recouping past investments: those in the be region. Given an unrestricted entitlement to decrease total $\mathrm{H}$, the firm would likely lay off those in the $e f(\mathrm{~W}>\mathrm{MP})$ phase while retaining those in the be $(\mathrm{MP}>\mathrm{W})$ phase. Since the ef workers are the highest wage workers, the consequence is that the firm could reduce its average wage rate, thus disguising a reduction in $\mathrm{W}$ by using its entitlement to set $\mathrm{H}$.

To avoid this potential for strategic behavior in adjusting $H$, the sunk-cost-loss rule forces the firm to follow a previously agreed upon schedule, typically based on seniority, which provides an ordering of layoffs. A seniority schedule requires the firm to lay off those workers in whom the firm is investing or recouping before it can lay off those workers who themselves are recouping. Thus, a seniority schedule effectively means that the firm increases its average wage as it makes layoffs. Such seniority provisions control recalls as well as layoffs: if the firm were to lay off senior workers owed deferred compensation, they would have to be recalled first if the firm increased its output in a future period.

The self-enforcing properties of the $\mathrm{W}^{*} \mathrm{H}$ test combined with the seniority schedule can be seen by referring to Figure 1 . The firm's po-

125 On the other hand, workers who have made specific investments in their training with the firm do suffer a sunk cost loss when the firm unilaterally cuts W. See id. at $130-31$. 
tential sunk cost loss in Figure 1 is the loss of its investment in the $a b$ region and the return on its investment in the be region. The firm must realize a loss on those workers before laying off the workers in the $e f$ region. The firm's potential sunk cost loss on workers in the $b e$ range acts as a buffer protecting the vulnerable workers in the $e f$ region.

As the next Section demonstrates, the $\mathrm{W}^{*} \mathrm{H}$ test combined with the seniority schedule successfully distinguishes on-site subcontracting (an impermissible cut in W) from partial closure (a permissible cut in total H). In certain complex cases, however, the seniority schedule provides an incomplete buffer because it does not apply across all relevant workers. These cases involve shifting work to an off-site subcontractor or relocating work to a different plant. Because the seniority schedule across plants is often incomplete, the firm may be able to disguise strategic cuts in W. That is, all workers, including those owed the most deferred compensation (in the $e f$ phase), might be laid off at one plant, while workers on whom the firm is recouping (in the be phase) were retained at a second plant or by a subcontractor. ${ }^{126}$ The self-enforcing properties of the $\mathrm{W}^{*} \mathrm{H}$ test are thus reduced in multiplant cases in which the different plants are not connected by cross-plant seniority provisions.

In these cases, a second test, the $\mathrm{K}$ test, is used to supplement the $\mathrm{W} * \mathrm{H}$ test. The $\mathrm{K}$ test focuses on physical capital $(\mathrm{K})$ inputs, such as plant and equipment. Under the $\mathrm{K}$ test, a firm is presumed to have incurred a sufficient sunk cost loss when it loses the value of the capital stock used by the workers in the affected plant. ${ }^{127}$ The $\mathrm{K}$ test imposes a second buffer, similar to that created by the seniority schedule: the firm must lose the plant-specific value of its physical capital, that is, the quasi-rents from this capital, before it can cut its labor costs.

The $\mathrm{K}$ test has self-enforcing properties similar to the $\mathrm{W}{ }^{*} \mathrm{H}$ test. In a conjectural setting, workers agree to deferred compensation while the firm agrees to post a bond not only in the form of its investment and return on junior workers in the plant, but also in the value of the firm's physical capital used in the plant. The contract is self-enforcing

${ }^{126}$ The retained $b e$ workers at the second plant might be either workers already employed there in the subcontracting case or workers transferred from the old plant in the relocation case. For further discussion of this point in the context of relocation, see infra notes 195-200 and accompanying text.

${ }^{127}$ The firm need not completely abandon the physical capital. Typically, the firm will sell the assets it plans not to use any longer. If the price the firm receives is minimal, such as mere scrap value, the firm has suffered a sunk cost loss. However, the higher the price the firm receives for its idled physical assets, the more likely it is that the firm has not incurred a sunk cost loss. In the extreme, if the firm sells its physical capital at a price sufficient to finance the replacement of this capital, it suffers no sunk cost loss. 
to the extent that the buffers represented by both the junior workers and the physical capital are greater than the deferred compensation owed to the senior workers.

When a decline in the product market begins, the firm starts discharging its junior workers as, at the same time, the economic value of the firm's capital investment begins to decline. By the time the product market has declined enough to lead to an $\mathrm{H}$ cut affecting workers in the $e f$ stage, the junior workers will have already been laid off and the capital equipment will typically have a much reduced value; this means the buffers will have vanished. Hence the $\mathrm{W}^{*} \mathrm{H}$ and $\mathrm{K}$ tests would be satisfied when the firm has no junior workers remaining in the idled plant and the remaining $\mathrm{K}$ equipment is not transferred to the new plant, but is idled. Alternatively stated, relocation or off-site subcontracting is more likely to be strategic to the extent that workers junior to the senior worker at the first plant are retained at the subcontractor's plant or transferred to the firm's second plant and capital equipment is transferred or sold for close to its use value in the closed plant.

\section{B. The Sunk-Cost-Loss Rule and the Protection of Default Entitlements}

The sunk-cost-loss rule is an economic rule, not a legal rule. Fashioning labor law principles from the sunk-cost-loss rule requires integrating the rule into the framework of default entitlement settings developed in the previous Part. Three cases must be differentiated: conjectural cases; nonconjectural cases covered by the contract; and nonconjectural cases not covered by the contract. The sunk-cost-loss rule provides the legal default setting only for the third case: a nonconjectural situation in which the collective agreement is either silent or ambiguous.

The sunk-cost-loss rule plays no direct role in conjectural cases because no sunk cost loss has yet occurred, and, in any case, there is less need to restrict the use of bargaining rules. In the conjectural stage, there is no issue of whether a product market decline has occurred; both parties agree that they are bargaining over future contingencies. Consequently, the firm has less asymmetric information that it can use strategically. Additionally, the sunk-cost-loss rule does not affect cases in which the collective agreement contains explicit allowances of or restrictions on the firm's means of adapting to product market conditions. The parties may explicitly adopt or override the sunk-cost-loss rule in the collective agreement. If the parties write explicit contingent agreements in the conjectural stage, then, in the nonconjectural stage, the Board and the courts protect with property rules the specific contingent 
entitlements "contained in" the collective bargaining agreement. ${ }^{128}$ The contract terms must, however, be sufficiently specific in defining the relevant contingency and the permitted response to ensure that the terms show a conscious attempt by the parties to create contingent entitlements. $^{129}$

\section{G. Objections to the Sunk-Cost-Loss Rule}

Several possible objections to the sunk-cost-loss rule merit discussion. The first objection is that, under certain conditions, the sunk-costloss rule might not be self-enforcing and hence would not deter all strategic labor cost cutting by the firm. Such a problem would occur, for example, if the contract between the firm and the older workers contained insufficient buffer protection when it was originally signed.

The major safeguard against such occurrence is that a union, as the bargaining representative of the workers, is unlikely to sign such one-sided agreements in the conjectural stage. An additional safeguard is that if the product market decline is not too sudden and unanticipated, then even in the nonconjectural stage the workers will have opportunities to escape from anticipated future losses in deferred compensation by bargaining for higher current wages, higher severance pay, supplementary unemployment benefits, or other clauses that raise the costs that the firm faces when laying off workers. Moreover, the sunkcost-loss rule is not the only deterrent of strategic behavior. The firm's reputational effects deter some strategic behavior. Firms that develop a reputation for strategic behavior will find that workers are unwilling to accept contracts containing deferred compensation. As a result, the firm's monitoring costs and training costs would increase, and its ability to hire high-quality workers would decrease. ${ }^{130}$ Although reputational effects will not deter a firm that completely closes its operations, they will deter firms that have other plants or other operations at the same plant. Finally, the Board and courts can further deter strategic behavior

${ }^{128}$ See NLRA § 8(d), 29 U.S.C. § 158(d) (1982) (statute "shall not be construed as requiring either party to discuss or agree to any modification of the terms and conditions contained in a contract for a fixed period"); supra note 100 and accompanying text.

129 Compare Ador Corp., 150 N.L.R.B. 1658, 1660 (1965) (employer action upheld because management rights clause specifically allowed the action to be taken) with Leeds \& Northrup Co. v. NLRB, 391 F.2d 874, 877-78 (3d Cir. 1968) (mere catchall phrase in the contract was not sufficiently clear and unmistakable to indicate that union relinquished rights).

130 See R. Ehrenberg \& R. Smith, supra note 10, at 406-07; Carmichael, Reputations in the Labor Market, 74 AM. ECON. REv. 713, 723 (1984). 
by determining that a firm's actions are due to antiunion animus. ${ }^{131}$ When a firm's actions are motivated by a desire to replace union workers, absent a business justification, the doctrine of antiunion animus could be applied to prevent the firm's actions. This protection may be particularly important in cases involving new unions that are negotiating their first contract.

A second objection to the sunk-cost-loss rule is that even if it deters all strategic behavior by the firm, it still may provide insufficient protection for the workers. This objection has an efficiency prong and an equity prong. The efficiency prong stems from the fact that business cycle fluctuations pose risks that workers may want to insure against, even if they are assured that the firm is not behaving strategically. ${ }^{\mathbf{1 3 2}}$ Either the parties in their collective agreement or the law through default settings must allocate the risk of economic downturns. Thus, risk bearing is a separate issue independent of the potential for strategic behavior.

Although a separate issue, the allocation of risk is determined jointly by the same contractual provisions and legal default settings that limit the firm's entitlement to adjust to product market declines. Specifically, the parties themselves allocate risk when they write seniority provisions, severance pay clauses, or other such mechanisms for compensating laid off workers. ${ }^{133}$ Similarly, the law, by preserving a duty to bargain over effects, ${ }^{134}$ or sometimes by implying severance provisions, ${ }^{135}$ provides insurance protection to workers.

131 See Textile Workers Union v. Darlington Mfg. Co., 380 U.S. 263, 275 (1965) ("[A] partial closing is an unfair labor practice . . . if motivated by a purpose to chill unionism in any of the remaining plants . . . if the employer may reasonably have foreseen that such closing would likely have that effect."); NLRA \& 8(a)(3), 29 U.S.C. $\S 158(a)(3)$ (1982) (It is an unfair labor practice for an employer "by discrimination in regard to hire or tenure of employment or any term or condition of employment to . . . discourage membership in any labor organization.").

132 For a general discussion of the economics of risk and insurance, see A. PolinSKY, supra note 1, at 51-56. Workers may want to insure against business risks because they have fewer opportunities to diversify than participants in financial markets. See supra note 34.

${ }^{133}$ See M. Stone, Labor-Management Contracts at Work 9 (1961); see also 2 Collective Bargaining Negot. \& Cont. (BNA) 53:1-2 (1986) (among employment contracts sampled, $52 \%$ provided for some income maintenance, but only $25 \%$ of nonmanufacturing contracts and only $6 \%$ of manufacturing contracts guaranteed work or pay).

${ }_{134}$ "Effects bargaining" will be discussed in the next Part. See infra notes 197200 and accompanying text.

${ }_{195}$ See, e.g., Flintkote Co. v. Textile Workers Union, 243 F. Supp. 205, 212 (D.N.J. 1965) (summary judgment denied on issue of whether, absent a substantive provision regarding severance pay in the collective bargaining agreement, there existed "an implied covenant [for the employer] to pay wages to employees after plant closure prior to expiration of the term of the collective bargaining agreement"). 
Although these provisions reduce risk, they do not completely eliminate it because of moral hazard. Moral hazard occurs when an individual is insured against a risk, and therefore has incentives to select the less costly option of not taking further precautions to reduce the probability of the risk occurring. In particular, workers fully insured against layoff would have an incentive to shirk on the job because they would be just as well off if they lost their jobs as if they kept them.

The equity prong of the objection that the sunk-cost-loss rule insufficiently protects workers is that the rule insufficiently protects union wage gains. There are several responses to this objection. First, it can be argued that the NLRA seeks to protect only "competitive," not cartelized, wage rates. ${ }^{136}$ By creating a statutory scheme that does not compel unionization, Congress forced unions and unionized firms to compete in the market place against the nonunion sector. High union wage premiums (unrelated to deferred compensation) can lead to negative economic profits for unionized firms and the flow of capital from the unionized to the nonunionized sector. Thus, if the intent of the NLRA is that the unionized sector survive and compete successfully in the marketplace, union wage premiums cannot be fully protected.

The second response is that internal labor markets seek to protect only the competitive returns accruing to monitoring and specific training. The higher the wage, the more likely it is that the firm, rather than the worker, is incurring those investment costs. In the extreme, if the wage is so high that unionized workers' wages exceed their opportunity wages throughout the job life cycle, then the workers have made no investments that need to be protected from strategic behavior. In construing collective bargaining agreements, one must consider not only the wage term itself, but also the terms that were explicitly or implicitly traded away to secure the wage term. In particular, wages can be viewed as implicitly traded off against employment security. ${ }^{137}$ The lower the wage, the lower the firm's costs. Low cost status helps to protect the firm from the worst effects of business cycle fluctuations. In addition, the lower the firm's wage costs, the more likely the firm is to retain workers during declines. Thus, in bargaining for high present wages rather than investing in their specific training or monitoring,

138 See NLRA $\S 1,29$ U.S.C. $\S 151$ (1982) (describing the inequality of bargaining power that "prevent[s] the stabilization of competitive wage rates and working conditions within and between industries").

137 Wages may also be traded against an employer's bad reputation. Suppose that a firm has a reputation for acting strategically. Workers might respond by writing high present-wage contracts rather than contracts containing deferred compensation. 
workers may be viewed as implicitly trading away the higher degree of job security to which deferred compensation would entitle them.

\section{An Application of the Sunk-Cost-Loss Rule to Leading Labor Law Cases}

This Part analyzes several major cases involving subcontracting work, partially closing a plant, and relocating plant operations. ${ }^{138}$ They all occur in the nonconjectural stage and involve economically based decisions costly to union workers but unmarred by antiunion animus.

The following discussion will point out the underlying economic logic that supports these decisions and will demonstrate how future lawmakers may approach the problem in a more explicitly consistent and economically coherent manner. Most of the cases reach the result that would have been achieved if the Board and the courts had explicitly used the sunk-cost-loss rule. This fact is not surprising if, as this Article has argued, labor law is largely concerned with the efficient functioning of internal labor markets.

\section{A. The Supreme Court Framework}

The Supreme Court has twice addressed the scope, absent a contravening agreement, of management prerogatives to respond to product market declines. ${ }^{139}$ In Fibreboard Paper Prods. Corp. v. $N L R B,{ }^{140}$ the Court held that at least some subcontracting was subject to mandatory bargaining. Seventeen years later, in First National Maintenance Corp. v. NLRB, ${ }^{141}$ the Court held that the partial closure of a business

138 For an excellent survey of NLRB and court decisions in this area, see P. Miscimarra, The NLRB and Managerial Discretion: Plant Glosings, RelocaTIONS, SubCONTRACTING, AND Automation (1983). Unfortunately, this study predates Otis Elevator II, 269 N.L.R.B. 891 (1984), and Milwaukee Spring II, 268 N.L.R.B. 601 (1984), affd sub nom. UAW v. NLRB, 765 F.2d 175 (D.C. Cir. 1985), the two relocation cases discussed in this Article.

130 In Fort Halifax Packing Co. v. Coyne, 107 S.Ct. 2211, 2214 (1987), the Supreme Court upheld a Maine law requiring employers that terminate operations at plants with 100 or more employees or that relocate those operations more than 100 miles away to "provide one week's pay for each year of employment to all employees who have worked in the plant at least three years." Id.

This Article does not address the issue of state laws designed to supplant the default settings of federal labor laws and to replace federal laws with their own default settings. The Maine law, ME. REv. Stat. ANN. tit. 26, § 625-B (Supp. 1986-87), however, is consistent with the sunk-cost-loss rule in that it does not interfere with the employer's decision but instead mandates certain "default effects," which overwrite the federal default setting of effects bargaining and which the parties may in turn overwrite in the collective agreement.

140379 U.S. 203, 209 (1964).

${ }^{141} 452$ U.S. 666,686 (1981). 
was an entitlement belonging to the firm and protected by a property rule. Although many commentators have struggled to reconcile these two cases, ${ }^{142}$ the internal labor market model and the sunk-cost-loss rule provide a justification for the decisions in these cases and also for much of the analysis used by the Court.

\section{Fibreboard}

In Fibreboard, a firm decided to subcontract for plant maintenance work upon expiration of its collective bargaining agreement, which provided for automatic renewal absent notice to modify or terminate the contract. The union workers had performed the maintenance work for over twenty years. The firm claimed that the maintenance work had become too costly and that an independent contractor could do the work more cheaply. The firm did not consult or bargain with the union about its decision to subcontract nor did it give the contractually required notice. ${ }^{143}$

The Supreme Court held that the firm committed an unfair labor practice by not bargaining over the subcontracting decision, which the

142 Two commentators reconcile the cases in ways similar to this Article's approach. See Campbell, supra note 4, at 1022 (requiring mandatory bargaining over subcontracting decisions, but over only the effects of partial closure, correctly balances labor's interest in making the demand for labor less elastic with management's interest in restricting production to optimal levels); Harper, Leveling the Road from BorgWarner to First National Maintenance: The Scope of Mandatory Bargaining, 68 VA. L. REV. 1447, 1463-64 (1982) ("decisions concerning how employers are to compensate organized laborers from the wealth generated by their work" differs from "decisions concerning what goods will be produced and offered to which markets"; the former are for bargaining, the latter only for management response to consumer preferences).

For general discussion and criticism of the First National Maintenance decision, see The Supreme Court, 1980 Term, 95 Harv. L. Rev. 91, 329 (1981); Comment, Job Security, Managerial Prerogatives, and First National Maintenance, 31 Bufralo L. REv. 509, 521-46 (1982); Comment, Labor Law-The Employer's Duty to Bargain over a Decision to Close Part of Its Business, 12 Mem. ST. U.L. Rev. 185, 185-95 (1981); Note, Collective Bargaining over Plant Relocation Decisions: Let's Make a Deal, 18 New Eng. L. Rev. 715, 732-40 (1983); Note, Labor Law-A Balancing of Interests Test Applied to the Duty to Bargain About a Partial Closing Decision: First National Maintenance Corp. v. NLRB, 61 N.C.L. REv. 365, 365-77 (1983); Note, Employer's Duty to Bargain with Respect to Partial Termination of Business: First National Maintenance Corp. v. NLRB, 36 Sw. L.J. .793, 801-05 (1982); Note, Enforcing the NLRA: The Need for a Duty to Bargain over Partial Plant Closings, 60 TEx. L. Rev. 279, 292-302 (1982); Note, Labor Law-An Employer's Decision to Terminate Partially a Business Operation Is Not a Mandatory Subject of Bargaining, 56 Tul. L. Rev. 1065, 1074-82 (1982); Comment, Labor Law: An Employer's Duty to Bargain Concerning the Decision to Terminate Part of a Business, 34 U. FLA. L. REv. 292, 292-303 (1982); Note, supra note 4, at 951-68.

143 See Fibreboard, 379 U.S. at 205-06. The union, however, did give timely notice of its desire to modify the contract. See id. at 205. Thus, the contract was due to expire at the-time the dispute arose, making the case an endterm case. 
Court deemed a mandatory subject of bargaining. ${ }^{144}$ Although the Court made several arguments in support of its conclusion, ${ }^{145}$ the heart of the opinion recognized the economic effect of subcontracting:

The Company's decision to contract out the maintenance work did not alter the Company's basic operation. The maintenance work still had to be performed in the plant. No capital investment was contemplated; the Company merely replaced existing employees with those of an independent contractor to do the same work under similar conditions of employment. ${ }^{146}$

Thus, the Court focused on the fact that the subcontracting at issue merely substituted cheaper nonunion labor for more expensive union labor at no additional cost to the firm. ${ }^{147}$

In an influential concurrence, Justice Stewart accepted this economic interpretation of the firm's subcontracting decision. According to Justice Stewart, "All that is involved is the substitution of one group of workers for another to perform the same task in the same plant under the ultimate control of the same employer." 148 Nevertheless, Justice Stewart attempted to limit some of the broad language in the majority opinion. ${ }^{148} \mathrm{He}$ argued that mandatory bargaining rules should not be applied to managerial decisions that "lie at the core of entrepreneurial control,"150 including decisions concerning "what shall be produced, how capital shall be invested in fixed assets, or what the basic scope of the enterprise shall be."151

144 See id. at 209.

145 The Court first stated that the subcontracting at issue fell within the literal meaning of "terms and conditions of employment" under $\$ 8(\mathrm{~d})$. Id. at 210 . Second, the Court noted that requiring mandatory bargaining in this case would further the purposes of the Act by promoting "the peaceful settlement of industrial disputes" through negotiation. Id. at 210-11. Third, the Court looked to industrial practice and found that subcontracting was addressed successfully in many collective agreements. See id. at 211-12. Fourth, the Court found the case to be merely an extension of Local 24, Int'l Bd. of Teamsters v. Oliver, 358 U.S. 283, 294-95 (1959), which held piecemeal subcontracting to be subject to mandatory bargaining. See Fibreboard, 379 U.S. at 21213. 679-80.

${ }^{146}$ Fibreboard, 379 U.S. at 213, quoted in First Nat'l Maintenance, 452 U.S, at

${ }_{147}$ The Court explicitly declined to extend its holding to "other forms" of subcontracting. Fibreboard, 379 U.S. at 215.

${ }^{148} I d$. at 224 (Stewart, J., concurring).

149 Justice Stewart worried that "there are passages in the Court's opinion today which . . . seem[] to imply that any issue which may reasonably divide an employer and his employees must be the subject of compulsory collective bargaining." Id. at 221 (Stewart, J., concurring).

${ }_{100} I d$. at 223 (Stewart, J., concurring).

${ }^{161} I d$. at 225 (Stewart, J., concurring) (emphasis added). At another point, Jus- 
In the context of the internal labor market model presented in the last two Parts, both opinions in Fibreboard are consistent with the sunk-cost-loss rule. The economic effect of the subcontracting in Fibreboard is a cut in the wage rate (W) without a reduction in total hours $(\mathrm{H}){ }^{\mathbf{1 5 2}}$ Although the firm reduces the hours of work of its own workers, it maintains $\mathrm{H}$ and hence its total output and revenue by buying labor services through a subcontractor. In addition, although the firm does not change the wage rate it pays to its remaining workers, substituting the lower wage employees of a subcontractor to do the "same work under similar conditions of employment" effectively reduces the firm's average $W$ across total $\mathrm{H}$. By reducing the average wage rate and maintaining total hours (including those of the subcontractor), a firm engaged in such subcontracting violates the $\mathrm{W}{ }^{*} \mathrm{H}$ test and therefore the sunk-cost-loss rule. ${ }^{153}$

The critical point is that the subcontracting firm can cut labor costs without incurring any sunk cost losses. Because the potential for strategic behavior in such a situation is great, the parties in a low transaction cost setting would not assign to the firm the unilateral right to engage in Fibreboard-type subcontracting. Thus, the default setting implied by the sunk-cost-loss rule would be a bargaining rule and not a property rule entitlement allowing the firm to subcontract in this way. Justice Stewart's concurrence, however, implicitly recognizes that

tice Stewart's concurrence also includes "those management decisions which are fundamental to the basic direction of a corporate enterprise." Id. at 223 (Stewart, J., concurring) (emphasis added). Justice Stewart's concurrence does not define "scope" and "direction," but it is likely that he intended what economists define as "scale" and "scope," respectively. Scale ("scope" in Justice Stewart's terminology) refers to the size of the enterprise, while scope (Justice Stewart's "direction") refers to the number of different types of products produced, as well as the production technology used.

From an economic standpoint, Justice Stewart's "scope and direction" test largely parallels the $\mathrm{W}^{*} \mathrm{H}$ and $\mathrm{K}$ tests of the sunk-cost-loss rule. A change in scope can be interpreted as a cut in $\mathrm{H}$; a change in direction as a loss of $\mathrm{K}$. Justice Stewart's test departs from the majority opinion, which states at one point that the economies that "could be derived by reducing the work force . . . have long been regarded as matters peculiarly suitable for resolution within the collective bargaining framework." Id. at 213-14.

162 See id. at 224 (Stewart, J., concurring) (Fibreboard involved only the substitution of one workforce for another, resulting in a lower wage rate).

${ }_{183}$ The Court's decision limited the union's default entitlement, however, to one protected by a bargaining rule. See id. at 210 . The Court could have decided that the union had a property rule entitlement to prevent the firm from subcontracting. There are several possible reasons that the Court did not give a property rule entitlement to the union. First, the case occurred endterm, and bargaining rules are relatively more efficient than property rules at endterm, see supra notes 106-16 and accompanying text. Second, the Court may have feared that providing the union with a property rule entitlement in the nonconjectural stage would enable the union to extract high concessions from the firm in return for allowing subcontracting that posed no threat of strategic behavior by the firm. 
subcontracting can be a nonstrategic means of adjustment and that, consistent with the sunk-cost-loss rule, there may be situations in which a firm contemplating subcontracting to reduce its labor costs could be deterred from behaving strategically. For example, if the subcontracting results in a change "in the basic scope of the enterprise" (a reduction in $\mathrm{H}$ in our terminology), the firm might incur a sunk cost loss large enough to verify that the subcontracting was efficient rather than strategic. Similarly, if a change in "invest[ment] in fixed assets"154 accompanies the subcontracting, the firm may suffer a substantial sunk cost loss from outdated physical capital that the firm abandons or sells at a value substantially below replacement cost. In contrast, if a firm were allowed to replace senior workers at its plant with junior workers of the subcontractor, or transfer all of its physical capital to the subcontractor, there would be neither a change in basic direction nor an investment in fixed assets and thus no sunk cost loss. Presumably Justice Stewart would have construed this type of subcontracting as a mandatory subject of bargaining.

\section{First National Maintenance}

The second Supreme Court case, First National Maintenance, confirmed the Court's implied willingness to allow a firm to act unilaterally in response to market declines when the firm incurs a sunk cost loss. First National Maintenance, which performed maintenance services for other businesses, ${ }^{185}$ laid off all the workers assigned to a nursing home when First National terminated its maintenance contract with the home. The cancellation of the contract resulted not directly from labor costs, but from a dispute over the amount of the fee to be paid above labor costs. Although the newly elected bargaining representative requested bargaining over First National's decision to terminate the nursing home contract, First National refused. . $^{\text {158 }}$

The Supreme Court held that First National did not have to bargain over the "decision" to terminate the maintenance contract with the nursing home and to lay off the workers employed under that contract. ${ }^{157}$ In making this determination, the Court found controlling the fact that the firm's decision "involv[ed] a change in the scope and direc-

164 Fibreboard, 379 U.S. at 225 (Stewart, J., concurring).

${ }^{155}$ It is interesting to note that First National Maintenance presents a fact pattern that is almost a mirror image of Fibreboard. First National was in the role of a subcontracting maintenance company, like the firm the Fibreboard employees were hoping to stave off.

${ }^{156}$ First Nat'l Maintenance, 452 U.S. at 668-70.

167 Id. at 686. 
tion of the enterprise."158 On the other hand, the Court ruled that the firm had to bargain over the "effects" of the partial closing. ${ }^{159}$

Thus, the Court gave the firm an entitlement protected by a property rule to lay off workers when it partially closed its operations. Largely adopting Justice Stewart's analysis in Fibreboard, ${ }^{160}$ the Court formulated the following balancing test: "bargaining over management decisions that have a substantial impact on the continued availability of employment should be required only if the benefit, for labor-management relations and the collective-bargaining process, outweighs the burden placed on the conduct of the business."161

In applying this test, the Court can be viewed as having implicitly analyzed the costs of bargaining rules compared with those of property rules in nonconjectural cases. The Court discussed three ways in which property rule entitlements were relatively less costly than bargaining rules. ${ }^{162}$ First, the Court recognized the potential for strategic behavior by the union under a bargaining rule: "Labeling this type of decision mandatory could afford a union a powerful tool for achieving delay, a power that might be used to thwart management's intentions in a manner unrelated to any feasible solution the union might propose."163 Second, the Court acknowledged management's "need for speed, flexibility, and secrecy in meeting business opportunities and exigencies,"164 which mandatory bargaining and its informational requirements would render difficult. Finally, the Court noted the remaining protections available to the union under a property rule, such as effects bargaining, mandatory bargaining in the conjectural stage, and prohibition of decisions based on antiunion animus. ${ }^{165}$

Given this implicit balancing of property rules versus bargaining rules, the Court attempted to distinguish the partial closure situation in First National Maintenance from the subcontracting decision in

158 Id. at 677.

159 Id. at 677 n.15 \& 681. First National did not dispute the NLRB's conclusion that it had committed an unfair labor practice by refusing to bargain over effects and in fact reached agreement with the union on severance pay. See id. at 678 n.15.

${ }^{160}$ See id. at 677 . The Court also relied in part on the analysis of the Fibreboard majority. See id. at 679-80 (noting the Court's implicit recognition of the employer's freedom to make management decisions).

161 Id. at 679.

${ }^{162}$ Cf. supra notes 101-03 and accompanying text (discussing the transaction costs of negotiations, use of economic weapons, and required provision of information).

${ }^{183}$ First Nat'l Maintenance, 452 U.S at 683.

164 Id. at $682-83$.

185 See id. at 681-82. In addition, the Court, as in Fibreboard, looked to industrial practice and found that "provisions giving unions a right to participate in the decisionmaking process concerning alteration of the scope of an enterprise appear to be relatively rare." Id. at 684 . 
Fibreboard. The Court argued that the "decision to halt work at this specific location represented a significant change in petitioner's operations, a change not unlike opening a new line of business or going out of business entirely."168 The Court contrasted such a decision with a decision "to replace the discharged employees or to move that operation elsewhere"; ${ }^{167}$ the Court, however, did not explain satisfactorily the basis for its distinction.

In particular, the Court was unclear about the issue of "labor costs." On the one hand, the Court stated that "a desire to reduce labor costs," as in Fibreboard, is " "peculiarly suitable for resolution within the collective bargaining framework." "188 On the other hand, the Court maintained that "[i]f labor costs are an important factor in a failing operation and the decision to close, management will have an incentive to confer voluntarily with the union to seek concessions ....."169 While the former statement is consistent with the economic rule, ${ }^{170}$ the latter argument is troubling. Part of the problem is that these arguments focus on the wrong question. The relevant issue is whether the firm is potentially acting strategically in cutting its labor costs, not whether the firm has an incentive to bargain.

The sunk-cost-loss rule articulates the distinction that provides a principled rationale for the Court's ruling in First National Maintenance. The economic effect of a partial closure is to cut the level of employment, and therefore the level of production. This drop in production makes the partial closure similar to "going out of business" and

186 Id. at 688 .

187 Id. at 687.

188 Id. at 680 (quoting Fibreboard, 379 U.S. at 214). Conversely, the Court stated that if labor costs are not "a crucial circumstance in a particular economically based partial termination... the Board's traditional remedies may well be futile." $I d$. at 685. Thus, because the dispute was "solely over the size of the management fee," $i d$. at 687 , requiring bargaining would not have helped the union. The dissent correctly rebutted this argument by noting that "[e]ven where labor costs are not the direct cause of a company's financial difficulties, employee concessions can often enable the company to continue in operation . . . Id. at 690 (Brennan, J., dissenting).

Moreover, Professor Gorman, in his critique of First National Maintenance, argues that "all of the respondent's investment consisted of its labor costs (even the tools, equipment, and materials were furnished by the nursing home), concerning which the workers and the union had an indisputable influence." Gorman, The Negligible Impact of the National Labor Relations Act on Managerial Decisions to Close or Relocate, 58 Tul. L. REv. 1354, 1362 (1984). Although these are valid criticisms, they lead only to disagreement with the Court's reasoning in this instance, not with its conclusion.

${ }_{169}$ First Nat'l Maintenance, 452 U.S. at 682.

170 The consistency depends on how labor costs are defined, however. The Court cited Fibreboard, 379 U.S. at 213-14, in which the Court included reductions in work force as an example of a decision particularly suitable for bargaining. See First Nat'l Maintenance, 452 U.S. at 680 . If labor cost reduction includes work force reduction, the Court's statement is not fully consistent with the sunk-cost-loss rule. 
not similar to "replacing discharged employees." Both subcontracting and partial closure reduce the wage bill $(\mathrm{W} * \mathrm{H})$, but Fibreboard-type subcontracting does it by reducing the wage rate $(W)$, while partial closure does it by reducing the size of the labor force $(\mathrm{H})$ in accordance with the seniority schedule. Thus, only partial closure satisfies the $\mathrm{W}^{*}$ $\mathrm{H}$ test. ${ }^{171}$

It is worth noting that the facts in First National Maintenance are unusual because First National's technology required almost no capital. ${ }^{172}$ First National's workers used the equipment owned by the customer on that customer's premises. ${ }^{173}$ Although atypical, the facts in First National Maintenance suggest that the firm's decision was efficient rather than strategic. First, there was little doubt that First National had in fact suffered a product market decline. The firm lost a customer, the nursing home, and by cutting the $\mathrm{H}$ associated with that customer, the firm suffered a sunk cost loss on whatever investments it did make in its workers and capital. Second, there was no evidence that the firm used this lost contract as a subterfuge to avoid deferred compensation. In fact, it is possible that there was little deferred compensation owed to the workers, in which case the gains from strategic behav-

171 Professor Campbell comes close to stating this distinction between subcontracting and partial closure in his brief discussion of Fibreboard and First Nat'l Maintenance. In attempting to reconcile the two cases from an economic perspective, he argues that workers "should be allowed to bargain over issues concerning substitution for labor in production, but should not be allowed to influence product market decisions, such as how much output is manufactured." Campbell, supra note 4, at 1022. Nevertheless, Campbell's focus is different from that of this Article. He frames his economic approach to labor law around the question of the scope of monopoly power accorded to unions rather than around the minimization of strategic behavior in internal labor markets through efficient contracting. See $i d$. at 1005-06.

In addition, Professor Harper advocates a rule he calls the "product market principle" which would exclude from mandatory bargaining "all decisions to determine what products are created and sold, in what quantities, for which markets, and at what prices." Harper, supra note 142, at 1463. Applying this rule to First Nat'l Maintenance, Harper argues that the Court's decision was correct because the partial termination constituted the withdrawal of a product from the market. See id. at 1469. Harper distinguishes Fibreboard subcontracting because it "do[es] not change the nature of the good that the contracting employer ultimately offers to the market." Id. at 1475. Although Harper's analysis is close to that of this Article, it is closer to Campbell's analysis in that its roots are in antitrust principles rather than internal labor market principles.

172 Professor Gorman, for one, finds decisive "the fact that the respondent's decisions in no way affected the investment or withdrawal of capital, the basic scope and direction of the enterprise, and similar factors so prominently mentioned in Fibreboard . . . "Gorman, supra note 168, at 1362. In this Article's view, a cut in $\mathrm{H}$ is as much a change in the "scope and direction" of an enterprise as a change in $\mathrm{K}$ and usually ensures a sufficient sunk cost loss, although, in a more complex situation involving combinations of cuts in $\mathrm{W}$ and $\mathrm{H}$, the absence of a $\mathrm{K}$ loss could make the case more difficult.

${ }^{173}$ See First Nat'l Maintenance, 452 U.S. at 668. 
ior would have been slight. ${ }^{174}$ Third, although the union was newly formed at the time of the dispute, and thus the partial closure could have been the result of antiunion animus (the Court left open this possibility), there was no evidence of this problem on the facts presented. Finally, any remaining potential for strategic behavior was mitigated by the Court's affirmation of mandatory bargaining over effects.

\section{Summary of Supreme Court Framework}

The Court's framework establishes that in nonconjectural, endterm cases, labor law awards a property rule entitlement to the firm when the firm adjusts to product market declines by cutting total hours of work in accordance with a seniority schedule. Alternatively, a bargaining rule applies in nonconjectural, endterm cases in which the firm adjusts by effectively cutting the wage rate through subcontracting. Fibreboard-type subcontracting is therefore a mandatory subject of bargaining, but First National Maintenance-type partial closure is not.

In formulating the default entitlements in these two cases, the

174 Professor Alchian, discussing First National Maintenance from an economic perspective, concludes that the workers probably had not invested in specific training. More precisely, he argues that any specific quasi-rents (returns to specific training) owing to the workers were not created in response to offers by the firm to invest in such specific training. Thus, Professor Alchian argues that the workers did not have any interest that needed to be protected. See Alchian, supra note 4, at 244-45.

Although this Article shares Professor Alchian's focus on internal labor markets, it disagrees with the implications of his analysis of First National Maintenance. Alchian's analysis implies a rule based on the presence or absence of investments in specific training. In contrast, this Article adopts a rule based on the presence or absence of a sunk cost loss. The sunk-cost-loss rule is closer to the Supreme Court framework. Moreover, it is more efficient than the "specific training rule," which, standing alone, is both underprotective and overprotective of workers in the internal labor market.

The specific training rule is underprotective because it fails to recognize that any deferred compensation, even when not related to specific training, gives rise to the potential for strategic behavior by the firm. Deferred compensation need not be associated with specific training, but may be related to monitoring or take the form of the mobility or search costs saved when workers remain at their current jobs. Under the sunk-costloss rule, a cut in $\mathrm{W}$ to avoid deferred compensation is impermissible even if there is no evidence of investment in specific training. In contrast, the specific training rule apparently would have allowed First National to engage in Fibreboard-type subcontracting because the workers had no protectable interest. Thus, such a rule fails to reconcile Fibreboard and First National Maintenance.

The specific training rule is also overprotective of workers in cases of true product market decline because it fails to recognize the firm's need to respond efficiently to changes in the product market. Under the sunk-cost-loss rule, a cut in $\mathrm{H}$ in accordance with the seniority schedule assures that the firm is taking a loss. Therefore, such a cut is permissible even if the laid off workers had made some investments in specific training. In contrast, the specific training rule would have prohibited the partial closure had there been evidence of investment in specific training. It is difficult to reconcile this result with either the Supreme Court's analysis or efficient contracting principles. 
Court was sensitive to how the parties themselves would allocate the entitlements. In both cases, the Court referred to industrial practice in making its decision. ${ }^{175}$ Under the Court's analysis, when a contract term is widely used, a court can use that contract term as a first approximation to the default settings that the parties themselves would have established. This approach is entirely consistent with the economic approach to labor law developed herein. ${ }^{176}$ In addition, this Article has provided an economic rationale for those relevant stylized, or widely used contract terms, found in internal labor markets.

The rules applicable to these cases do not apply when the parties are in the conjectural stage or when the collective agreement contains a pertinent provision. Bargaining rules predominate in the conjectural stage. Thus, a union wanting to bargain for a work preservation clause that prevented a future partial closure during the term of the contract could insist on such a clause until impasse resulted. Moreover, entitlements created by the collective agreement itself are enforced as specified in the contract, even if they override the sunk-cost-loss rule, since the sunk-cost-loss rule is merely a property rule default setting. Thus, if the union agrees to a provision permitting Fibreboard-type subcontracting, it must abide by this agreement.

\section{B. Subcontracting and Partial Closure Under the Supreme Court Framework}

Given the Fibreboard and First National Maintenance dichotomy, the Board has been faced with the task of distinguishing labor cost cutting governed by bargaining rules from that governed by property rules. It has had to address essentially two types of cases: subcontracting that closely resembles a "partial closure" of the firm's operations and relocation of firm work to another one of its own plants. Thus far, the Board has struggled to fashion a workable analysis from the two Supreme Court cases. This Section applies the sunk-cost-loss rule to some of the recent subcontracting cases. The following Section examines the Supreme Court's framework for the relocation issue.

${ }^{175}$ See First Nat'l Maintenance, 452 U.S. at 684 (The Court found it significant that "provisions giving unions a right to participate in the decisionmaking process concerning alteration of the scope of an enterprise appear to be relatively rare. Provisions concerning notice and 'effects' are more prevalent."); Fibreboard, 379 U.S. at 211-12 (The Court stated that, "[w]hile not determinative, it is appropriate to look to industrial bargaining practices in appraising the propriety of including a particular subject within the scope of mandatory bargaining.").

${ }_{178}$ But see Alchian, supra note 4, at 237-38 (arguing that the focus should be on implicit understandings between disputing parties, not on provisions in typical contracts). 
One year after First National Maintenance, the Board, in Bob's Big Boy Family Restaurants, ${ }^{177}$ had occasion to analyze the effect of that opinion on subcontracting decisions. Bob's Big Boy involved a restaurant chain that owned a "commissary" plant, which prepared and distributed food for the firm's restaurants. One of the departments in the plant was the shrimp processing department, whose employees were responsible for cutting, breading, and packaging shrimp. Because of "the escalating market price of raw shrimp and the problems encountered in . . . portion control,"178 Bob's decided to purchase processed shrimp from an outside firm. Bob's laid off the shrimp processing employees, converted the processing area to storage, returned its cutting machines to the lessor, sold its breading machines to the subcontractor, and modified its oil hydraulic system for use in another department. The firm did not bargain with the union over this decision or its effects.

The Board majority held that the firm violated section $8(a)(5)$ by failing to bargain with the union about the decision to subcontract. ${ }^{179}$ The majority found the situation more like the subcontracting in Fibreboard than the partial closure in First National Maintenance, because the firm "still supplies processed shrimp to its constituent restaurants. The only difference is that the processing work is now performed by [the subcontractor's] employees . . . A Accordingly, the nature and direction of [Bob's] business was not substantially altered by the subcontract." 180 Thus, even though the firm itself "closed down the shrimp processing operation," 181 as the dissent maintained, the firm did not change the production level of processed shrimp that it ultimately supplied to its restaurants. ${ }^{182}$

The majority's analysis comports with the sunk-cost-loss rule. Bob's Big Boy was cutting its labor costs without cutting back its scale of operations. The firm's decision, therefore, did not meet the $\mathrm{W} * \mathrm{H}$ test and was not a partial closure in the First National Maintenance

177264 N.L.R.B. 1369 (1982).

178 Id. at 1369.

178 The majority also upheld the Administrative Law Judge's finding that Bob's violated $\S 8(\mathrm{a})(5)$ by failing to bargain over the effects of its decision to discontinue its shrimp processing operation. See $i d$.

180 Id. at 1371 (footnote omitted). part).

181 Id. at 1373 (Van de Water \& Hunt, concurring in part and dissenting in

${ }_{182}$ The majority also noted that Bob's primary concerns in deciding to subcontract-escalating costs and portion control- although not involving labor costs directly, were nevertheless suitable for resolution through mandatory bargaining. Declining to follow the First Nat'l Maintenance "labor cost" analysis, the majority reasoned that "production cost matters . . . by their very nature include wages, fringe benefits, and other employment costs, over which the union can exercise substantial control." Id. at 1371. 
sense.

The firm also failed to satisfy the $\mathrm{K}$ test since it did not incur substantial sunk cost losses on its physical capital. According to the majority, Bob's Big Boy did not "engage in any substantial capital restructuring or investment."183 In addition, the firm was able to return, sell, or convert all of the machines used in the shrimp processing department, at no apparent loss. Moreover, the shrimp processing area was not left vacant but was converted to storage. Thus, Bob's actions satisfied neither component of the sunk-cost-loss rule; the Board's decision, therefore, that this subcontracting was a mandatory subject of bargaining is consistent with the economic rule's assignment of a bargaining rule in this situation. ${ }^{\mathbf{1 8 4}}$

A more recent subcontracting decision, Garwood-Detroit Truck Equipment, Inc. ${ }^{188}$ reveals the difficulty in staying within the economic rationale underlying Fibreboard and First National Maintenance without explicit statements of the sunk-cost-loss principles. Garwood mounted and serviced truck equipment and sold truck parts. In response to ongoing financial losses, ${ }^{186}$ Garwood laid off its mounting and service employees and, without bargaining with the union beforehand, retained a subcontractor to perform the mounting and service work for Garwood's customers. The subcontractor performed this work at Garwood's plant using the same equipment that Garwood's unionized workers had used. In addition, the subcontractor paid a percentage of Garwood's rent and utility bills, a monthly fee for the rental of Garwood's equipment, and procured liability and other insurance for Garwood's benefit. ${ }^{187}$

The Board held that Garwood-Detroit did not have to bargain over its subcontracting decision. ${ }^{\mathbf{1 8 8}}$ The majority asserted that bargaining was not necessary because the subcontracting decision "did not turn on labor costs-although labor costs were one component of the over-

183 Id.

184 It is possible, however, that the "storage" usage was in fact minimal and that the firm did incur significant losses as a result of discontinuing its shrimp processing operation. Conversely, the shrimp processing area might have occupied a very small proportion of the total plant area, so that any loss would have been minimal. The important point is that the sunk-cost-loss rule suggests the facts that are necessary for the Board to resolve subcontracting cases in an economically meaningful way.

185274 N.L.R.B. 113 (1985).

186 The employer indicated in its original notice to the union that it intended to subcontract work in response to "the present dire economic conditions presently prevailing in the ... area." Id. at 113.

${ }_{187} I d$. at 115 .

188 As in Bob's Big Boy, the majority upheld the Administrative Law Judge's finding that the firm committed an unfair labor practice by failing to bargain over effects. See id. 
head costs [Garwood-Detroit] intended to reduce by the subcontracting - but rather turned on a significant change in the nature and direction of its business: a decision to abandon its service and mounting operations."189 On the facts presented, the Board majority appears to reach an economically unsound result. In contrast, Member Dennis's dissent more closely follows the sunk-cost-loss test and the Board's decision in Bob's Big Boy. ${ }^{190}$ The dissent implicitly recognizes that the $\mathrm{W}^{*}$ $\mathrm{H}$ component of the sunk-cost-loss rule had not been met, since "the same work is still being provided at the same location to the same customers." 191 That is, the firm did not cut its total $\mathrm{H}$. Although it may have contemplated the elimination of its service and mounting operations, ${ }^{192}$ at the time the firm made its subcontracting decision, the firm had not yet committed itself to divestiture and thus did not "abandon" this aspect of the business. In addition, the firm did not meet the $\mathrm{K}$ test: it mitigated any sunk cost losses it might otherwise have suffered by leasing the work area and selling the equipment to the subcontractor.

Not only is the Garwood-Detroit dissent more consistent with the sunk-cost-lost rule, but it is also fully compatible with the test stated by the majority, which follows Otis Elevator II. ${ }^{183}$ Subcontracting that does not involve a sunk cost loss "turns on labor costs" to the extent that wage cuts are perfect substitutes for such cost cutting. The union, instead of offering wage concessions, could offer to pay a percentage of the firm's rent, utility bills, and insurance, just as the subcontractor did. ${ }^{194}$ Even under the majority's test, therefore, the subcontracting should have been prohibited. In many circumstances the labor cost test will probably be interpreted consistently with the sunk-cost-loss rule. The sunk-cost-loss rule, however, is a simpler, more direct statement of the efficient contracting rule adopted by the Supreme Court.

180 Id. The majority also rejected the Administrative Law Judge's conclusion that the subcontracting constituted a midterm modification in violation of $\S 8(\mathrm{~d})$. Thus, this case differs from the cases discussed so far in that it arose during the term of an existing collective agreement. Full discussion of the midterm issue is postponed, however, until presentation of Milwaukee Spring II. See infra notes 236-43 and accompanying text.

190 See Garwood, 274 N.L.R.B. at 117 (Dennis, dissenting in part).

191 Id. at 117 (Dennis, dissenting in part).

192 See id. at 115 ("[Garwood-Detroit] was contemplating divesting itself of its large shop equipment . . . .").

193269 N.L.R.B. 891 (1984). See infra notes 206-10 and accompanying text. Otis Elevator II held that the determinative distinction is whether the decision was based on labor costs rather than a change in the nature or direction of the business. See Otis Elevator II, 269 N.L.R.B. at 899.

194 For a more detailed comparison of the labor cost test and the sunk-cost-loss rule, see infra notes 218-19 and accompanying text. 


\section{G. Work Relocation Under the Supreme Court Framework}

\section{The Economics of Relocation}

Work relocation presents an economically more complex problem than subcontracting or partial closure because relocation involves multiplant firms. Two new issues are raised.

First, in adjusting to changed product market conditions, a multiplant firm will be driven by profit maximization to consolidate work among its various plants. Profit maximization requires that the multiplant firm set the level of output in such a way as to equalize the marginal costs at each plant; thus, work flows from high to low marginal cost plants. Due to economies of scale and differences in technology across plants, even a small decline in product demand could require large changes in staffing or hours of work at different plants. If a firm does not have the entitlement to adjust output to realize economies of scale, its profits could be highly vulnerable. A firm unable to consolidate work through relocation could be driven from the market entirely. Therefore, a firm, in a low transaction cost setting, would not sign a contract that so restricted its ability to adjust.

Second, the potential for strategic behavior is increased by the fact that the firm must face two groups of workers rather than one group. In single plant cases, one firm "jointly maximizes" with one group of workers or, in a unionized firm, with the agent of those workers. ${ }^{195}$ In multiplant cases, however, the workers in the two (or more) plants may either be in different bargaining units ${ }^{198}$ or one group of workers may not be unionized. As a result, the two groups of workers and the firm may not be able to develop a cross-plant layoff schedule comparable to the seniority schedule within a single plant.

These two novel features of work relocation pose a dilemma. The need to realize economies of scale strengthens the case for giving the entitlement to the firm, as long as it satisfies the sunk cost loss rule. But the problem of two groups of workers weakens the power of the $\mathrm{W}^{*} \mathrm{H}$ test to restrict strategic behavior by itself.

195 The main economic justification for unions in internal labor markets is that the union acts as an agent of the workers. Because the union has the exclusive right to bargain on behalf of all workers in the bargaining unit, the union can overcome freerider problems that otherwise exist and thus facilitate joint profit-maximizing contracts. See, e.g., Fischel, supra note 4, at 1071-74.

${ }^{108}$ If the workers in the different plants were in the same bargaining unit, the problems posed by two or more groups of workers would not arise. The NLRB uses the "community of interests" standard to determine which employees should be included in a bargaining unit. See R. Gorman, supra note 69, at 68-69. Thus, if the employees are in separate units, they do not share a community of interests. 
In the polar case, when a firm, in the process of consolidation, cuts total $\mathrm{H}$ across plants by the amount of the decline in $\mathrm{H}$ in the high cost plant (the victim-plant of the relocation), the $\mathrm{W}^{*} \mathrm{H}$ test remains sufficient. Such a relocation resembles a First National Maintenance-type partial closure.

If, on the other hand, the relocation involves only a partial change in total $\mathrm{H}$ (that is, there is an increase in $\mathrm{H}$ at the low-cost plant that is close to the decrease in $\mathrm{H}$ at the high-cost plant), then the relocation resembles Fibreboard-type subcontracting. Such relocations primarily involve a reduction in wages. In particular, if the increase in $\mathrm{H}$ at the low-cost plant involves transferring junior workers from the high-cost plant, then the relocation would carry a great potential for strategic behavior. Such a relocation may nevertheless be permitted if the firm satisfies the $\mathrm{K}$ test, which looks to the $\mathrm{K}$ loss at the high cost plant. If, for example, the firm has closed the high cost plant and scrapped the equipment, then the $\mathrm{K}$ loss satisfies the sunk cost loss rule. Although the multiplant firm may be allowed to relocate some of the equipment along with the work, the greater the amount of $\mathrm{K}$ that is relocated, the less likely that the move will satisfy the $K$ test.

Thus, in these relocation cases, the sunk-cost-loss rule involves a calculation that compares the sum of the losses in the firm's investments in $\mathrm{K}$ and $\mathrm{H}$ with the senior workers' deferred compensation. If the firm's losses in $\mathrm{K}$ and $\mathrm{H}$ investments are large relative to the deferred compensation owed to the workers in the high cost plant, the firm would have the entitlement to relocate. In contrast, when the firm strongly mitigates these losses, the union would have the entitlement.

In certain cases, the firm may satisfy the sunk-cost-loss rule even though it proposes to transfer some junior workers. In such cases, "effects bargaining" could be used as additional protection for senior workers. Under effects bargaining, although the firm would have the entitlement to relocate after having absorbed a sunk cost loss, the firm would have a duty to bargain with the workers in the high cost plant regarding which workers would be displaced. Mandatory bargaining over effects is, in fact, the entitlement protection that the Board typically accords to workers in relocated plants. ${ }^{\mathbf{1 9 7}}$ Effects bargaining in

197 See First Nat'l Maintenance, 452 U.S. at 681-82; see also Chippewa Motor Freight, Inc., 261 N.L.R.B. 455, 460 \& n.12 (1982) (employer must bargain over effects regardless of employer's bankruptcy); Whitehall Packing Co., 257 N.L.R.B. 193, 195 (1981) (order to bargain regarding effects on employees of decision to transfer unit operations); Burgmeyer Bros., 254 N.L.R.B. 1027, 1028 (1981) (order for management to bargain with union over effects of closing operations). This entitlement typically requires the employer to discuss such matters as severance pay, accrued vacation and other pay, pension rights, transfer to other company locations, and retraining. See 
relocation cases is broader than effects bargaining in subcontracting and partial closure cases, which mainly involves severance pay and recall schedules.

At this point, it is unclear how effects bargaining works in practice. While some legal scholars suggest that effects bargaining accords little protection to the workers, ${ }_{2}^{198}$ others contend that it could be tantamount to decision bargaining. ${ }^{199}$ The less protection effects bargaining provides to workers in practice, the weaker is the case for its use as a means of constraining the firm's relocation entitlement. ${ }^{200}$

As a final point, one must keep in mind the basic tenet that the law only fixes the default settings. Given the difficulties of effects bargaining or of adjudication of the issue, the parties are themselves likely to devote more attention to the problem during contract formation. Given the inherent conflict between the need to consolidate and the existence of two groups of workers, the current uneasy solution may be the best available. The firms would retain the right to relocate, but not to transfer junior workers from the closed plant. The workers, in turn, would capture their deferred compensation in the form of higher current wages, severance pay, and other such provisions.

Gorman, supra note 168, at 1367.

198 See Gorman, supra note 168, at 1367-69. Gorman argues that in most relocation cases there will not be

a credible union threat of economic pressure, either because the facility at which they work will close imminently anyway and there will be no other company facility nearby at which a picketing appeal can be made, or because the employees on the brink of termination will likely have little appetite to undertake a strike effort.

Id. at 1368 .

${ }^{198}$ See Kohler, Distinctions Without Differences: Effects Bargaining in Light of First National Maintenance, 5 InDuS. REL. L.J. 402, 421 (1983) ("[B]ecause 'effects are so inextricably interwoven with the decision itself,' there seems no way to prevent bargaining over the former from having an impact on the latter." (quoting Ozark Trailers, Inc., 161 N.L.R.B. 561, 570 (1966))).

200 On the other hand, the more effects bargaining protects workers, the more likely it will nullify the firm's decision entitlement. One of the key issues involving effects bargaining is the time at which the union has a right to be notified of the need for such bargaining. See P. MiscimarRa, supra note 138, at 162-66; Kohler, supra note 199, at 416-18. At least one court of appeals has held that the firm has no duty to bargain over effects until a decision to relocate is actually made. See NLRB v. National Car Rental Sys., Inc., 672 F.2d 1182, 1188 (3d Cir. 1982). If notice is required before a decision is made, effects bargaining and decision bargaining would almost certainly merge. In this case, effects bargaining may not be desirable.

Thus, it may not be possible to promulgate rules governing effects bargaining that preserve the firm's decision entitlement yet provide meaningful protection to the workers. Kohler notes that the distinction between the time a firm becomes committed to its decision and the time the firm implements the decision "is a fine one at best. In reality, there may be no way to distinguish the timing." Kohler, supra note 199 , at 418 n.86. 


\section{Otis Elevator II}

Since First National Maintenance, the Board has had several opportunities to examine plant relocations. ${ }^{201}$ Two cases, Otis Elevator II and Milwaukee Spring $I I,{ }^{202}$ stand out as the major precedents in this still unclear area. Both demonstrate how the economic analysis developed in the previous Sections can resolve the issues in these and future relocation cases.

Otis Elevator II, decided after Milwaukee Spring II, presents the clearest statement of the Board's analysis of the plant relocation problem. After being taken over by United Technologies in 1975, Otis Elevator decided that its research and development operations at its Mahwah, New Jersey plant were outdated. Otis subsequently constructed a new research center at its headquarters in East Hartford, Gonnecticut, with the intention of consolidating its research and development activities there. ${ }^{203}$ Otis refused to bargain over its decision to relocate and transfer seventeen union employees to the new plant, as well as the effects of that decision.

The union filed unfair labor practice charges with the Board, which held in Otis Elevator $I^{204}$ that the firm had violated the Act by refusing to bargain over the relocation decision and its effects. While the appeal was pending, the Supreme Court decided First National Maintenance. As a result, the appeals court remanded the case to the NLRB and the Board reversed Otis Elevator $I .{ }^{205}$

The plurality in Otis Elevator II found First National Maintenance directly applicable to relocation, but eschewed the specific balancing test developed in First National Maintenance. ${ }^{206}$ Instead, the

201 See, e.g., Metropolitan Teletronics, 122 L.R.R.M. (BNA) 1107 (1986); Oak Rubber Co., 277 N.L.R.B. 1322 (1985); Inland Steel Container Co., 275 N.L.R.B. 929 (1985).

${ }^{202}$ Milwaukee Spring Div. of Ill. Coil Spring Co., 268 N.L.R.B. 601 (1984), affd sub nom. UAW v. NLRB, 765 F.2d 175 (D.C. Cir. 1985).

${ }^{203}$ United Technologies had a research and development center in East Hartford to which some Otis employees from a different New Jersey plant had previously been transferred. See 269 N.L.R.B. at 892.

204255 N.L.R.B. 235 (1981).

205269 N.L.R.B. 891 (1984) [Otis Elevator II]. A plurality of the Board decided the case, with Member Dennis concurring separately and Member Zimmerman concurring in part and dissenting in part.

${ }_{206} \mathrm{See} i d$. at $891,893-94$. In contrast, Member Dennis, in her concurrence, closely followed First National Maintenance in analyzing Otis Elevator's decision to relocate:

The first step is to determine whether ... the employer's decision is "amenable to resolution through the bargaining process.". . .

... The second step in the analysis . . . involves weighing the fact that the decision is amenable to resolution through the bargaining process 
plurality adopted what it felt to be a more predictable test that relied on Justice Stewart's Fibreboard concurrence as incorporated by First National Maintenance. Under this test,

the critical factor to a determination whether the decision is subject to mandatory bargaining is the essence of the decision itself, i.e., whether it turns upon a change in the nature or direction of the business, or turns upon labor costs; not its effect on employees nor a union's ability to offer alternatives. ${ }^{207}$

The plurality thus reasoned that the crucial difference between Fibreboard and First National Maintenance was that Fibreboard's decision "turn[ed] upon a reduction of labor costs," tional Maintenance's action was based on a change in the "scope, direction, or nature of the business.",209

Given this test and the facts of Otis, the plurality concluded that the relocation decision was not a mandatory subject because it turned upon a fundamental change in the nature and direction of the business and not upon labor costs. ${ }^{210}$ In addition, the Board, over the dissent of Member Zimmerman, remanded to the Administrative Law Judge (ALJ) the determination of whether the firm engaged in an unfair labor practice by refusing to bargain over the effects of the relocation. ${ }^{211}$

("the benefit") against the constraints that process places on management ("the burden").

Id. at 897 (Dennis, concurring) (citations omitted) (punctuation altered).

Member Zimmerman did not advocate the First National Maintenance balancing test. He argued that a relocation decision is a mandatory subject "when the decision is amenable to resolution through collective bargaining." Id. at 900 (Zimmerman, concurring in part). Zimmerman also argued for this rule in his dissent in Milwaukee Spring II. See Milwaukee Spring II, 268 N.L.R.B. at 605.

For a general discussion of Otis Elevator II that contends the NLRB failed to apply properly the First National Maintenance balancing test, see George, To Bargain or Not to Bargain: A New Chapter in Work Relocation Decisions, 69 MiNN. L. REv. 667, 686-95 (1985).

${ }^{207}$ Otis Elevator II, 269 N.L.R.B. at 892.

208 Id. at 893.

209 Id.

210 The plurality stated:

[Otis] made its decision because of its opinion that its technology was dated, its product was not competitive, its Mahwah research and development operation duplicated other operations, and because a newer and larger research and development center was available in East Hartford. These facts establish that the [Otis's] decision did not turn upon labor costs even though that factor may have been one of the circumstances which stimulated the evaluation process which generated the decision.

Id. at 892 (footnotes omitted).

${ }^{211}$ Id. at 894. Member Zimmerman "adher[ed] to the Board's findings in its ini- 
Recently, in Otis Elevator III, ${ }^{212}$ the Board upheld the ALJ's determination that the firm committed an unfair labor practice by refusing to bargain over the effects of its decision to transfer unit work. ${ }^{\mathbf{2 1 3}}$

The sunk-cost-loss rule leads to the same result reached by the Board: giving the firm an intermediate property rule entitlement to relocate, with mandatory bargaining over the effects. The relocation was an efficient move away from an outdated plant rather than a strategic ploy to avoid paying deferred compensation. Faced with a declining market share, Otis wanted to consolidate its research and development operations at its new plant to eliminate duplicative facilities and thereby reduce costs by taking advantage of economies of scale. Most likely, the pure $\mathrm{W} * \mathrm{H}$ test was not satisfied; any cut in $\mathrm{H}$ was a partial cut, because some workers were transferred. Nevertheless, the firm satisfied the $\mathrm{K}$ test by idling its old plant. ${ }^{214}$

On the other hand, the firm refused to bargain with the union over the transfer criteria and the individuals selected for the transfer. The previous subsection argued that allowing a firm to choose unilaterally which workers are to perform relocated work could permit strategic behavior. ${ }^{218}$ This problem can be resolved in two ways. First, as the Board determined in Otis Elevator $I I I,{ }^{218}$ the firm can be required to bargain over the effects of the relocation, including the issue of worker relocation. ${ }^{217}$ Second, as suggested in this Article, if the firm substantially mitigated its sunk cost loss by transferring junior workers, the decision to relocate could be interpreted as a failure to satisfy the sunkcost-loss rule.

Although the sunk-cost-loss rule and the Board's "labor cost" test reach the same result in Otis $I I$ and are largely compatible with each other, the Board's test is problematic. The first problem with this test involves the definition of "labor costs." Otis Elevator II is not clear on

tial decision ... that the company violated section $8(a)(5)$ of the Act by failing to bargain in good faith over the effects of the transfer decision. . . ." Id. at 901 (Zimmerman, concurring in part and dissenting in part).

212124 L.R.R.M. (BNA) 1334 (1987).

${ }^{213}$ The NLRB also upheld the ALJ's finding that Otis violated $\S 8(a)(5)$ and (a)(1) by bargaining directly with the employees to be transferred. See id. at 1337. However, the NLRB reversed the ALJ's finding that Otis did not bargain in good faith over the particular relocation package offered to the transferred employees. See id. at 1338.

214 The loss in the old plant most likely occurred gradually over time. In measuring the size of the firm's sunk cost loss on its physical capital, the relevant previous value of the capital is the value at the time the workers entered into the current contract containing deferred compensation.

215 See supra text following note 196.

216124 L.R.R.M. (BNA) 1334 (1987).

217 See supra notes $197-200$ and accompanying text. 
whether the phrase "labor costs" refers to the wage rate $(W)$ or to total labor costs $\left(\mathrm{W}^{*} \mathrm{H}\right)$.

Based on the sunk-cost-loss rule, labor costs must refer to $W$, not to $\mathrm{W} * \mathrm{H}$. If labor costs mean total labor costs, then under the Board's test a firm's decision to cut total hours due to overcapacity would be a mandatory subject. This result would be inconsistent with the economic rule implied in First National Maintenance. ${ }^{218}$

The more significant problem with the Board's test is that the effect of the action on labor costs must be compared with the effect of the action on the nature and direction of the business. The Board, however, has not clearly identified the economic factors that differentiate between the two components of the test. Obviously, given this lack of guidance, firms have an incentive to characterize actions that in an economic sense turn on labor costs as actions that involve a change in scope and direction. ${ }^{219}$

The sunk-cost-loss rule alleviates the problems presented by the Board's test by clarifying the economic facts that differentiate between scope and direction and labor costs. Specifically, if a case is about an effective cut in $\mathrm{W}$, without reductions in $\mathrm{H}$ or losses in $\mathrm{K}$, then the case "turns upon" labor costs and is not about nature and direction. Fibreboard is such a case. Alternatively, if the facts present evidence of sunk cost losses in $\mathrm{H}$ and $\mathrm{K}$, then the case is about nature and direction and not about labor costs. Otis Elevator II (K loss) and First National Maintenance ( $\mathrm{H}$ loss) are examples of such cases.

\section{Milwaukee Spring II}

The second influential plant relocation case, which actually preceded Otis Elevator II, is Milwaukee Spring II. This case involved the Illinois Coil Company, a manufacturing firm consisting of three plants. During the term of its collective bargaining agreement, Illinois Coil lost

218 The confusion can be traced to Fibreboard's grouping of the acts of "reducing the work force, decreasing fringe benefits, and eliminating overtime payments." 379 U.S. at 213. The First National Maintenance Court characterized all three actions as reductions in "labor costs." See 452 U.S. at 680 . Reductions in the work force, however, would reduce only the total labor costs, not the wage rate, and would therefore be permitted under the sunk-cost-loss rule.

${ }^{219}$ The Board thought $\S 8(\mathrm{a})(3)$ could prevent an employer from masking an intent to weaken a union by labeling a decision purely economic. See Otis Elevator $I I$, 269 N.L.R.B. at 892 n.4 (citing First Nat'l Maintenance, 452 U.S. at 682). But neither the Board nor the First National Maintenance Court offered any guidance about how to identify such mislabeling. Of course, if the decisions are clearly subterfuges designed solely to evade a collective agreement, the Board would find the decisions tainted by antiunion animus and therefore violative of $\S 8(\mathrm{a})(3)$. See Textile Workers Union v. Darlington Mfg. Co., 380 U.S. 263, 275-76 (1965). 
a major customer. As a result of this downturn in its product market, Illinois Coil tentatively proposed relocating its assembly operations from its unionized Milwaukee Spring plant to its nonunionized McHenry plant in order to take advantage of the lower wage rate at McHenry. Illinois Coil informed the union that it was willing to keep the assembly work at the Milwaukee Spring plant if the union would agree to wage and benefit concessions. After substantial bargaining, the union rejected these proposals and declined to bargain further. Illinois Coil then announced its decision to relocate the assembly operations. ${ }^{220}$

The union filed unfair labor practice charges with the Board. The parties stipulated that the relocation decision "was economically motivated and was not the result of union animus."221 In addition, the parties stipulated that the firm had bargained to impasse over the relocation decision and was willing to bargain over effects. In Milwaukee Spring $I,{ }^{222}$ the Board held that the company had violated the Act and ordered reinstatement of the employees. The firm appealed and was granted its motion to remand to the Board for further consideration. ${ }^{223}$ On remand, in Milwaukee Spring II, the NLRB reversed its earlier decision, over the dissent of Member Zimmerman. ${ }^{224}$ The union appealed, and the Court of Appeals for the District of Columbia Circuit affirmed the NLRB decision. ${ }^{228}$

The facts presented by the three opinions in Milwaukee Spring $I I$ suggest that the relocation decision was efficient rather than strategic because the sunk-cost-loss rule was satisfied. Although the facts do not specifically reveal whether the firm intended to cut $\mathrm{H}$ as a result of the relocation, the firm had just lost a contract with a major customer. ${ }^{226}$ Thus, it is almost certain that the firm would cut total $\mathrm{H}$ in conjunction with the relocation. To the extent that firm did not increase $\mathrm{H}$ at the second plant, the $\mathrm{W}^{*} \mathrm{H}$ test would have allowed the relocation. If $\mathrm{H}$ did increase at the second plant, the sunk-cost-loss rule would look to the $\mathrm{K}$ test.

The relocation may have satisfied the $\mathrm{K}$ test. Some equipment was transferred, ${ }^{227}$ which suggests only a small sunk cost loss, but the as-

${ }^{220}$ See Milwaukee Spring II, 268 N.L.R.B. at 601.

221 Id.

222265 N.L.R.B. 206 (1982).

${ }^{223}$ Milwaukee Spring II, 268 N.L.R.B. at 601.

224 See id. at 605.

225 See UAW Local 547 v. NLRB, 765 F.2d 175, 184 (D.C. Gir. 1985).

${ }^{226}$ In his dissent, Member Zimmerman notes that "[i]t is unclear from the record whether th[e] loss [of the contract] resulted in a decreased amount of assembly work, molding work, or other work." Milwaukee Spring II, 268 N.L.R.B. at 608-09 n.5 (Zimmerman, dissenting).

${ }^{227}$ See id. at 608 (Zimmerman, dissenting). 
sembly work represented one-third of the work performed at the Milwaukee Spring plant, ${ }^{228}$ which suggests a larger sunk cost loss. Even if the firm mitigated some of its $\mathrm{K}$ losses, meeting the $\mathrm{W} * \mathrm{H}$ test is sufficient to satisfy the sunk-cost-loss rule. Of course, if the Board had specifically applied the sunk-cost-loss rule, different facts might have come to light to suggest a potentially strategic rather than efficient relocation.

Application of the sunk-cost-loss rule to the facts of Milwaukee Spring II is complicated by the fact that the case presents not only the economic issues specifically relevant to relocation, but also the related legal analysis generally applicable to midterm disputes. In law and economics terminology, the case involves two important issues: which party gets the default entitlement regarding midterm relocation and how this entitlement is to be protected. The three opinions in Milwaukee Spring II-the Board majority, the court of appeals decision, and the Board dissent-apply very different analyses to these two issues. The next subsections compare and evaluate these various approaches against the economic approach to midterm entitlement protection and the sunkcost-loss rule.

\section{a. Board Majority}

The Board majority based its ruling that there was no unfair labor practice on narrow legal grounds. According to the majority, the contract between Illinois Coil and the union was silent on the subject of relocation; hence, the relocation did not modify the collective agreement in violation of section 8 (d) of the NLRA. ${ }^{229}$ In addition, the majority reasoned that without any relevant term "contained in" the collective agreement, the most the firm had to do was bargain before it relocated. ${ }^{230}$ Since the firm bargained with the union over its decision to relocate and stood willing to bargain over effects, the firm had met its statutory obligations.

The Board majority correctly refused to imply a work preservation clause, that is, an absolute property rule entitlement for the union. ${ }^{231}$ The opinion recognized that giving the union an absolute entitlement protected by a property rule would, in effect, give the union "veto power"232 over midterm plant relocation, which the union then could

${ }^{228}$ See id. (Zimmerman, dissenting).

${ }^{228}$ See id. at 602 ("[W]e have searched the contract in vain for a provision requiring bargaining unit work to remain in Milwaukee.").

${ }_{230}$ See id.

231 See id.

232 Id. at 605. 
use strategically to obtain costly concessions from the firm and hinder efficient work shifting.

But the majority avoided determining whether the contested relocation was a mandatory subject of bargaining. Instead, it assumed arguendo that relocation was a mandatory subject. ${ }^{233}$ As a result, the Board majority never answered clearly either the question of which party had the entitlement regarding relocation or the question of how the entitlement was to be protected midterm. ${ }^{234}$

\section{b. Court of Appeals}

Unlike the Board decision, the court of appeals opinion ${ }^{235}$ focused on the question of how midterm entitlements should be protected. The court analytically separated this question from the question of which party should get the entitlement. Thus, the opinion is the most useful vehicle for comparing the legal and economic approach to these two issues.

\section{(i) Midterm Entitlement Protection}

The court of appeals first argued that because the relocation decision occurred midterm, the court had to decide the "threshold issue [of] whether . . . the relocation decision was 'contained in' the contract"236 and thereby subject to property rule protection midterm under section 8(d). The court assumed that the relocation decision was a mandatory subject $^{237}$ and reasoned that the decision was contained in the agreement as a result of either the management rights clause, implied management rights, or the zipper clause. ${ }^{238}$ The zipper clause dominated the other two possibilities because, under the court's broad interpretation, if an agreement contains a zipper clause, all mandatory subjects are deemed to be contained in the agreement. Thus, the court concluded that the presence of a broadly worded zipper clause precluded all

${ }^{233}$ See id. at 601 n.5.

234 A plurality did conclude, however, that "an employer need not obtain a union's consent on a matter not contained in the body of a collective-bargaining agreement even though the subject is a mandatory subject of bargaining." Id. at $603 \mathrm{Mem}$ ber Dennis did not join this part of the opinion. Thus, the plurality apparently would never assign a midterm property rule to the union as a default setting if the entitlement is not explicitly covered by the agreement.

${ }^{235}$ UAW Local 547 v. NLRB, 765 F.2d 175, 184 (D.G.Cir. 1985).

238 Id. at 181.

${ }^{237}$ See id. at 181 n.23.

238 See $i d$. at 180-82. From an economic perspective, a zipper clause may be viewed as merely an explicit statement by the parties of the entitlement protection method that would be implied in the absence of such a clause. 
midterm mandatory bargaining. ${ }^{23 \theta}$ Midterm bargaining could still occur, but it would be permissive rather than mandatory bargaining. The court, therefore, discerned two possible midterm outcomes: either the firm had a property rule entitlement to relocate because of the management rights clause or an implied management right, or the union had a property rule entitlement to prevent the relocation. ${ }^{240}$

Although the court's expansive interpretation of zipper clauses departs from the conventional legal treatment, ${ }^{241}$ the court's resolution of the issue of midterm entitlement protection is fully consistent with the economic approach taken in this Article. As argued in an earlier Part, ${ }^{242}$ bargaining rules are relatively efficient at endterm, but are relatively costly at midterm, especially in a nonconjectural situation. Even if bargaining rules are the least costly alternative at midterm, they may be ineffective. The union's ability to strike makes endterm bargaining rules effective. But during the term of most collective agreements, the strike option is usually foreclosed by the presence of a no-strike clause. Thus, mandatory midterm bargaining more closely resembles permissive endterm bargaining than mandatory endterm bargaining. ${ }^{243}$

\section{(ii) Default Entitlement Setting}

After deciding that the relocation entitlement is contained in the contract, a court must then decide in which explicit clause or implied term of the agreement the entitlement is zippered up. In the jargon of law and economics, having decided to protect midterm entitlements with property rules, the court must then decide which party gets the property rule entitlement. The D.G. Circuit maintained that the firm has a property rule entitlement to relocate contained in either the management rights clause or implied management rights. ${ }^{244}$ The court re-

239 See id. at 180.

240 See id. at 182-83.

241 The Board does not tend to find that a zipper clause waives bargaining rights unless the clause contains explicit restrictions or unless the negotiating history of the clause supports such a waiver. Courts of appeals, however, seem to be more willing to construe broadly worded zipper clauses as waivers. See P. MiscimarRa, supra note 138, at 76-78.

${ }^{242}$ See supra notes 106-16 and accompanying text.

243 The firm faced with a midterm bargaining rule entitlement need only bargain in good faith until an impasse is reached and then act unilaterally, as did Illinois Coil.

Of course, a union faced with a midterm bargaining rule could still succeed in offering concessions sufficient to induce the firm to trade away its entitlement. In fact, as Professor Schwab points out, the union in Milwaukee Spring did just that. See Schwab, supra note 4, at 247 n.7. The union offered (and the firm accepted) a wage concession, which resulted in no transfer of work and no loss of union jobs. See Milwaukee Spring II Upheld, Lab. L. Rep. (CCH) No. 696, at 1, 2 (June 21, 1985).

24 See UAW Local 547, 765 F.2d at 181-82. 
lied predominantly on the broadly worded management rights clause, which gave the firm the "exclusive right . . . to determine the operations or services to be performed in or at the plant . . . or to relieve employees because of lack of work or for other legitimate reasons . . . or to change . . . facilities."245 The court supported its interpretation of the management rights clause by indicating that the union conceded that the clause covered the contested relocation. ${ }^{246}$

The court's assignment of the entitlement to the firm is consistent with the economic approach, although the court bases its conclusion on a literal reading of the management rights clause rather than on an explicit analysis of the relevant economic facts surrounding the relocation. The economic approach would interpret a broad management rights clause in the same way that it would determine whether an entitlement was a mandatory subject of bargaining-by using the sunkcost-loss rule. The management rights clause under this approach codifies the sunk-cost-loss rule. In the clause used by Illinois Coil, for example, the "right . . . to relieve employees because of lack of work" corresponds to the $\mathrm{W} * \mathrm{H}$ test, while the "right . . . to change . . . facilities"247 corresponds to the $\mathrm{K}$ test. Hence, one can interpret the clause to cover efficient, but not potentially strategic, relocation. ${ }^{\mathbf{2 4 8}}$

On the other hand, if a midterm relocation violates the sunk-costloss rule, then it cannot be contained in a generic management rights clause. ${ }^{249}$ For example, relocation to avoid deferred compensation

245 ld. at 182 n.24.

${ }^{246}$ See id. at 182. This argument should not be pushed too far. First, the language of the management rights clause is somewhat ambiguous with respect to transfers of work from one plant to another. Second, it is possible that the reason the union "conceded" that the clause covered the relocation was that the union did not anticipate the court's broad interpretation of zipper clauses, which would have given the union a midterm property rule entitlement if the transfer entitlement had not been contained in the management rights clause. Finally, if one can look to the union's actions in determining whether the entitlement was contained in the clause, one can also look to the firm's actions. In this case, the firm bargained about the relocation and stipulated that the entitlement was a mandatory subject. If the firm had thought that the management rights clause applied, it might not have bargained at all.

${ }^{247}$ Id. at 182 n.24.

${ }^{248}$ One may wonder why a firm would include a management rights clause in a collective agreement if that clause does not enhance the rights of management. The firm may do so because it may be uncertain that the default setting will be observed in its absence. Inserting a boilerplate management rights clause into the contract is practically costless to the firm and deters the errant adjudicative body from misapplying the proper default setting. In addition, it is important to remember management rights clauses can add to the default entitlements of the firm if they are addressed to specific decisions and contingencies.

249 The court's opinion is not inconsistent with this interpretation. The court finds the entitlement contained in the management rights clause largely because the union did not present any convincing arguments to the contrary. It is, of course, possible that 
would not be a "legitimate reason" to "relieve employees" under the Illinois Coil clause, and the right to engage in such relocation would not be contained in that clause. Instead, the economic approach suggests that the Board find such a relocation contained in the wage provision of the collective agreement, because a violation of the sunk-cost-loss rule constitutes an effective wage cut.

\section{(iii) Unresolved Midterm Relocation Issues}

The court opinion leaves several issues unresolved. Because these issues will likely be present in future midterm relocation cases, it is useful to compare the court's analysis with the economic analysis of these issues.

First, the court suggests that arbitration be used in cases like Milwaukee Spring II to resolve the entitlement concerning the relocation decision. ${ }^{250}$ The court, however, offers no guidance about when the Board should defer to an existing arbitration award ${ }^{251}$ or an uninvoked arbitration procedure. ${ }^{252}$ Nor does the court offer guidance about what criteria arbitrators should use in making their decisions. Although the

the union could not find any persuasive arguments because none existed in this case. On the other hand, the court probably would have been willing to consider an argument by the union that the relocation was potentially strategic, and was therefore not permitted by the management rights clause.

${ }^{250}$ See Local 547 UAW, 765 F.2d at 182 n.26. The author of the opinion, Judge Harry Edwards, emphasizes this point even more strongly in an article published subsequent to the opinion. See Edwards, Deferral to Arbitration and Waiver of the Duty to Bargain: A Possible Way Out of Everlasting Confusion at the NLRB, 46 OHIO ST. L.J. 23, 32-33 (1985).

${ }^{251}$ The Board, however, has promulgated its own standards for deferral to an existing arbitration award. See Olin Corp., 268 N.L.R.B. 573, 574 (1984).

${ }^{262}$ See Collyer Insulated Wire, 192 N.L.R.B. 837 (1971) (holding that the Board can defer to arbitration even if the parties themselves have not invoked the arbitration process). Judge Edwards advocates an expansion of the Collyer doctrine to what he terms the "contractual waiver doctrine":

In the traditional Collyer-type case, the proper analysis is not one of deferral at all, but rather of waiver . . . I I believe that when the parties negotiate a collective bargaining agreement and stipulate that they will arbitrate disputes arising under it, they have waived many of their statutory rights under the NLRA. The parties' agreement, in essence, supplants the statute as the source of many employee rights in the context of collective bargaining.

Edwards, supra note 250, at 28. In particular,

where a dispute pertains to a waivable subject that is covered by the arbitration clause, the parties have waived their rights under the NLRA and have replaced them with the rights created by the contract. The parties have provided that disputes arising under the contract should be resolved by an arbitrator. The Board, therefore, is precluded from reaching the dispute and the arbitrator's decision is final.

Id. at 30 . 
issue of deferral is beyond the scope of this Article, if arbitrators are called upon to decide whether a relocation decision is contained in an agreement, the economic approach would offer the sunk-cost-loss rule to the arbitrator as the proper tool for a reasoned and fair analysis. ${ }^{253}$

Second, the court did not, nor did it have to, decide whether the firm had to engage in effects bargaining because the firm "stood willing to bargain over the effects of the move."254 Although the court might have required effects bargaining if faced with the issue, the court's broad reading of zipper clauses might eliminate even midterm mandatory bargaining over effects. The unresolved question under this approach is how to resolve the midterm property rule entitlement concerning effects. The economic analysis of relocation suggests that effects should not be deemed to be contained in the management rights clause. Instead, effects would be deemed to be contained in the layoff and severance clauses. If the parties' treatment of these effects is explicitly contained in the collective agreement, then obviously the entitlement setting will be clear. In relocation cases, however, because of the presence of more than one group of workers, cross-plant layoff schedules are rare. ${ }^{255}$ If, therefore, these clauses do not explicitly cover the effects of relocation-for example, if the layoff clause deals with intraplant but not cross-plant seniority-then an arbitrator or court must fill in the gaps.

${ }^{253}$ The scope of an arbitrator's authority is a well-recognized dilemma in labor law. See United Steelworkers v. Warrior \& Gulf Navigation Co., 363 U.S. 574, 583-85 (1960) (holding that unless there is specific language excluding a matter from arbitration, any question of coverage should be resolved in favor of arbitration). Typical contract language limits an arbitrator's authority by stating that the arbitrator cannot modify or add to any of the terms and provisions of a contract nor make any decisions on matters not covered by specific provisions of the contract. See, e.g., 2 Collective Bargaining Negot. \& Cont. (BNA) 51:281 (1986). An example of the dilemma is whether there should be judicial deference to an arbitrator's incorrect decision on a relocation clearly contained in the management rights clause because it involves a case of "lack of work" (the $\mathrm{W}^{*} \mathrm{H}$ test) or "change in facilities" (K test). Effects entitlements do not pose this dilemma because they would not be deemed contained in a broad management rights clause.

${ }^{254}$ Local 547 UAW, 765 F.2d at 181.

${ }^{255}$ See supra notes $195-96$ and accompanying text. A 1986 survey showed that $91 \%$ of the contracts surveyed include layoff provisions and $60 \%$ of the contracts permit an employee scheduled for layoff to displace less senior employees in other jobs (bumping). Of those contracts allowing bumping in specified areas, only $7 \%$ permit the practice throughout the company compared with $30 \%$ that permit bumping throughout the plant; $21 \%$ permit it only within the employee's division or department, and $37 \%$ restrict it to the employees' classification or group. Another $3 \%$ of the contracts surveyed allow bumping only to the employee's former job, classification, or group. See 2 Collective Bargaining Negot. \& Cont. (BNA) 60:1, 60:3 (1986); see also InduSTRIAL UNION Department, AFL-CIO, Comparative Survey of Major Collective BargainING AGREEMENTS 162-78 (1984). 
In determining the appropriate entitlement concerning default effects, the basic point to consider is that two groups of workers are involved. In particular, each group is likely to be explicitly or implicitly protected by an intraplant seniority clause that should be respected. Each group of workers is effectively protected by its own sunk-cost-loss rule. The layoff clause at the high-cost plant would therefore prevent the firm from transferring junior workers from the high-cost plant to the low-cost plant. The senior workers must be transferred first. On the other hand, the layoff clause at the low-cost plant would prevent the senior workers at the high-cost plant from bumping junior workers at the low-cost plant because the junior workers at the low-cost plant are not part of the buffer protecting the senior workers at the high-cost plant.

The final unresolved issue is whether the relocation decision is a mandatory subject of bargaining. The court, like the Board majority, never decided whether the relocation at issue in Milwaukee Spring II was a mandatory subject of bargaining, ${ }^{288}$ rather, both the majority and the court assumed arguendo that the relocation was a mandatory subject.

This issue becomes moot in midterm cases if property rule protection is used exclusively. ${ }^{257}$ If property rule entitlements replace bargaining rule entitlements at midterm, there is no need to determine whether a midterm relocation is a mandatory subject of bargaining.

It is interesting to note, however, that the economic test for deciding whether an entitlement is mandatory endterm parallels the test for deciding whether an entitlement is deemed contained in a management rights clause midterm. The sunk-cost-loss rule determines both issues. If a relocation, for example, satisfies the sunk-cost-loss rule, it is deemed efficient, in which case it is a nonmandatory bargaining subject governed by property rule protection for the firm at endterm and is contained in a management rights clause midterm. If, however, the relocation violates the sunk-cost-loss rule, it is deemed potentially strategic, in which case it is a mandatory bargaining subject that is governed

${ }^{258}$ See Local 547 UAW, 765 F.2d at 181 n.23.

257 This Article assumes that the parties have not agreed on a contractual provision that limits the firm's rights under the default setting. If the firm agrees to such a provision and then breaches the agreement, the firm does not commit an unfair labor practice-at least under $\S 8(\mathrm{a})(5)$-if the subject is nonmandatory. The union in that case is limited to traditional breach of contract remedies before a court. See Allied Chem. \& Alkali Workers, Local 1 v. Pittsburgh Plate Glass Co., 404 U.S. 157, 183-88 (1971). 
by mandatory bargaining at endterm and contained in the wage provision at midterm. ${ }^{258}$

\section{c. Board Dissent}

The third opinion, the dissent of Member Zimmerman, is unique in several respects. It is the only one of the three opinions that conflicts with the sunk-cost-loss rule on the facts presented. On the other hand, it alone explicitly focuses on the possibility of midterm property rule protection for the union based on the wage provisions in the agreement.

First, Zimmerman argues that the relocation was a mandatory subject of bargaining because it more strongly resembled the subcontracting in Fibreboard than the partial closure in First National Maintenance. ${ }^{259}$ Second, Zimmerman argues that the relocation, though not specifically prohibited by the contract, was nevertheless a midterm modification because it was motivated by "a desire to avoid a contractual term with regard to a mandatory subject of bargaining, such as wages." 260 Zimmerman's analysis of the first issue reaches a different conclusion than would the economic analysis. His resolution of the second issue is consistent with the economic approach.

In finding the relocation at issue to be a mandatory subject, Zimmerman identifies some of the facts relevant to the sunk-cost-loss rule analysis but fails to recognize the economic implications of those facts. In particular, he maintains that the firm was performing the same quantity of assembly work (that is, the firm was not cutting $\mathrm{H}$ ). $\mathrm{He}$ admits, however, that the record was "unclear" about the impact of the lost contract on total production and asserted that his conclusion would be the same "even if it resulted in less assembly work."261 Under the $\mathrm{W} * \mathrm{H}$ test, however, if the firm did in fact cut total $\mathrm{H}$, it would have a property rule entitlement to relocate.

In contrast with his treatment of the relocation issue, Member

${ }^{258}$ This Article does not mean to put forth a general theory of the use of bargaining rules midterm, an issue which has confounded the NLRB for some time. See, e.g., Jacobs Mfg. Co., 94 N.L.R.B. 1214 (1951) (company obligated to negotiate over issues of pensions but not of group insurance during the contract term), enforced, 196 F.2d 680 (2d Gir. 1952). In particular, this Article does not argue that all mandatory subjects are contained in a wage provision midterm, nor does it argue that all nonmandatory subjects are contained in a management rights clause. Rather, the point is that in dealing with issues concerning permissible adaptation to market conditions, the sunkcost-loss rule simultaneously serves two parallel functions: it determines whether an issue is mandatory endterm and interprets the meaning of management rights clauses midterm.

${ }^{259}$ See Milwaukee Spring II, 268 N.L.R.B. at 608-09 (Zimmerman, dissenting).

${ }^{280} I d$. at 611 (Zimmerman, dissenting).

${ }^{261}$ Id. at 608-09 n.5 (Zimmerman, dissenting). 
Zimmerman's resolution of the midterm entitlement issue is consistent with the economic approach. He argued that at midterm the union was protected by a property rule against the relocation because the relocation indirectly modified the wage provisions of the contract. ${ }^{262}$ The economic approach developed in this Article views Fibreboard-type subcontracting and some relocation as indirect wage cutting. Although Fibreboard holds that workers are protected against such indirect wage cutting by bargaining rules, not property rules, Fibreboard is an endterm case.

At midterm, the economic approach would advocate property rule protection of the wage term against both direct and indirect wage cutting. Thus, if Zimmerman were correct in his conclusion that the relocation in Milwaukee Spring constituted an indirect wage cut that violated the sunk-cost-loss rule, his determination that the workers have property rule protection midterm against such relocation would have extended the Fibreboard rule in a way consistent with efficient contracting principles.

\section{GONCLUSION}

This Article has argued that the labor law governing collective bargaining can be usefully analyzed from the perspective of efficient labor market contracting. This law and economics approach views labor law as addressing the market failure that exists in the internal labor markets of firms. External labor markets tend to be reasonably efficient, but internal labor markets suffer from the inefficiencies created by high monitoring costs and firm-specific investments, which lead to problems involving asymmetric information and strategic behavior.

The law and economics approach evaluates labor law's default settings against a standard of rules that the parties themselves would adopt if they were able to bargain in a low-transaction-cost environment. In such a context, the parties would write a joint profit-maximizing contract that would minimize both the costs of adjusting to new economic conditions and the potential for strategic behavior.

In applying the standard law and economics apparatus, this Article has argued that the National Labor Relation Act's statutory scheme adds a unique method of protecting entitlements-bargaining rulesthat supplement Calabresi and Melamed's classic division of inalienability, property, and liability rules. Bargaining rules force the parties to settle entitlement disputes between themselves by requiring bargaining

${ }^{282}$ See id. at 611 (Zimmerman, dissenting). 
over mandatory subjects and by allowing the parties to impose costs on each other in support of their positions. Bargaining rules are more efficient in conjectural and endterm disputes than in nonconjectural and midterm disputes. In these latter types of disputes, property rule protection is often more efficient.

Using these tools, this Article has evaluated the labor law concerning subcontracting, partial closure, and relocation, and has argued that in nonconjectural disputes, an efficient contracting solution gives an intermediate property rule entitlement to the firm over the decision, limited by the sunk-cost-loss rule. Under this rule, the firm has the unilateral right to adapt to product market changes, but it cannot do this by effectively cutting the wage rate; instead, it must incur a sunk cost loss in the form of a cut in total hours of work (the $\mathrm{W} * \mathrm{H}$ test) following a seniority schedule, and, in cases involving partial cuts in hours, idling of physical capital (the $\mathrm{K}$ test). Moreover, the rule does not give the firm a unilateral right to determine the effects of its decision, such as severance pay and cross-plant transfer schedules. The sunk-cost-loss rule has strong self-enforcement properties. The firm, forced to absorb a sunk-cost-loss in the process of exercising its entitlement is likely to find strategic behavior unprofitable.

This Article has applied the sunk-cost-loss rule to six leading labor law cases and argues that the Board and courts have implicitly used this rule in decisions from Fibreboard ${ }^{263}$ and First National Maintenance ${ }^{264}$ to Otis Elevator $I I^{265}$ and Milwaukee Spring $I I .^{268}$ In Fibreboard, the firm reduced the wage rate by subcontracting and did not take a sunk cost loss by cutting hours or idling capital; hence, the firm's potentially strategic decision was ruled an unfair labor practice. In First National Maintenance, on the other hand, the firm, in partially closing its plant, absorbed a sunk cost loss by laying off workers.

Two more recent cases, Bob's Big Boy ${ }^{267}$ and Garwood, ${ }^{268}$ help highlight the value of explicitly identifying the economic logic underlying the legal rule. Absent a clear statement of the economic model, inconsistent results may occur in more complex cases.

Finally, this Article analyzed Otis Elevator II and Milwaukee Spring $I I$, in which relocations were at issue, arguing that relocation poses a somewhat different set of economic problems than does subcon-

${ }^{263}$ Fibreboard Paper Prods. Corp. v. NLRB, 379 U.S. 203 (1964).

${ }^{264}$ First Nat'l Maintenance Corp. v. NLRB, 452 U.S. 666 (1981).

265269 N.L.R.B. 891 (1984).

${ }^{266} 268$ N.L.R.B. 601 (1984), affd sub nom. UAW v. NLRB, 765 F.2d 175

(D.C. Gir. 1985).

${ }^{267}$ Bob's Big Boy Family Restaurants, 264 N.L.R.B. 1369 (1982).

${ }^{268}$ Garwood-Detroit Truck Equip., Inc., 274 N.L.R.B. 113 (1985). 
tracting or partial closure because multiplant firms, and hence more than one group of workers, are involved. As a result, the $\mathrm{K}$ test has a larger role, as does the determination of which workers can be relocated to the surviving plant. In Otis, the Board implicitly followed the sunkcost-loss rule by allowing the firm to relocate away from an outdated plant while requiring effects bargaining over the transfer schedule.

The Board in Otis also articulated a test for determining the boundaries of management prerogatives in cases involving subcontracting, partial closures, and relocation. The test distinguishes decisions that turn on labor costs from those that affect the nature and direction of the business. This Article suggests that this test can be interpreted in a way that is entirely consistent with the sunk-cost-lost rule. When a firm accepts a sunk cost loss, it makes a change in the "scope or direction" of its business. In contrast, when the firm acts strategically to cut the wage rate without incurring a sunk cost loss, the firm makes a decision that is primarily about "labor costs."

Unlike the previous cases discussed, Milwaukee Spring II clearly presents the issue of how to protect midterm entitlements. The court of appeals adopted an efficient rule that effectively eliminates, or at least substantially narrows, the scope of midterm mandatory bargaining. Instead, the issue of which party should get the entitlement midterm is determined by an arbitrator, or by the Board or the courts, using property rules. Under this approach, entitlements concerning relocation are contained in either the management rights clause, as the court of appeals held, or the wage clause, as Board Member Zimmerman argued.

Whether an arbitrator or the court is called upon to determine the midterm entitlement, the sunk-cost-loss rule can be used to resolve the issue. If the relocation satisfies the sunk-cost-loss rule, then it is contained in the management rights clause, just as it would be a nonmandatory subject at endterm. On the other hand, if the relocation violates the sunk-cost-loss rule, then it is contained in the wage clause, just as it would be a mandatory subject at endterm. The facts presented in Milwaukee Spring II suggest that the court of appeals and the Board majority reached the efficient result consistent with efficient contracting. 
